\title{
Entrepreneurial education: entrepreneurial mindset and behavior in undergraduate students and professors
}

\author{
Ricardo Schaefer ${ }^{1}$, Italo Fernando Minello ${ }^{2}$ \\ ${ }^{1}$ Faculdade Antonio Meneghetti - ricardoschaefer@libero.it \\ ${ }^{2}$ Universidade Federal de Santa Maria - minelloif@gmail.com
}

Entrepreneurial education. Entrepreneurial mindset. Entrepreneurial behavior.

Received 19.01.2019

Reviewed 08.04.2019

Accepted 12.08.2019

ISSN 1980-4431

Double blind review

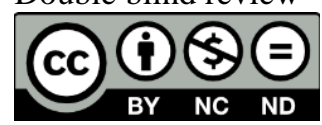

This study had the objective of analyzing the dimensions of the entrepreneurial mindset and the characteristics of the entrepreneurial behavior in undergraduate students and professors of a higher education institution that develops entrepreneurial education activities and projects. Its methodology is a theoretical-empirical research, with a quantitative approach, of the descriptive type. Data collection was performed using McClelland's Entrepreneurial Behavioral Characteristics Questionnaire (MSI, 1990), and Mannerelli's (2014) Forma Mentis Questionnaire to analyze the entrepreneurial mindset, and data were analyzed with statistical tests. It can be inferred, from the results of this research, that aspects of the entrepreneurial mindset and behavior can be developed in professors and students from a proposal of entrepreneurial education. The understanding of the entrepreneurial nature and how the entrepreneur thinks and acts can guide the actions to be carried out with the purpose of creating, especially in emerging countries, subjects, organizations and entrepreneurial environments that generate human development, competitiveness and economic growth, and social advancement.
PALAVRAS-CHAVE

Educação empreendedora. Mentalidade empreendedora. Comportamento empreendedor.

\section{RESUMO}

O presente estudo teve o objetivo de analisar as dimensões da mentalidade empreendedora e as características do comportamento empreendedor de alunos e professores de graduação de uma instituição de ensino superior que desenvolve atividades e projetos de educação empreendedora. Como metodologia, trata-se de pesquisa teórico-empírica, com enfoque quantitativo, do tipo descritivo. A coleta dos dados foi realizada por meio do questionário de características comportamentais empreendedoras de McClelland (MSI, 1990), e do questionário forma mentis para analisar a mentalidade empreendedora, de Mencarelli (2014), e os dados foram analisados a partir de testes estatísticos. Pode-se inferir, a partir dos resultados desta pesquisa, que aspectos da mentalidade e do comportamento empreendedores podem ser desenvolvidos em discentes e docentes a partir de uma proposta de educação empreendedora. A compreensão da natureza empreendedora e de como pensa e age o indivíduo empreendedor pode nortear as ações a serem realizadas com o propósito de criar, sobretudo em países emergentes, sujeitos, organizações e ambientes empreendedores, que gerem desenvolvimento humano, competitividade e crescimento econômico, e avanço social. 


\section{Introduction}

The development and improvement of the entrepreneurial spirit have been placed, not only in Brazil, but also in many emerging countries, as priority in the political, economic and academic agendas, given the proven influence that it has on the social and economic development of a nation (Krüger 2019). The socioeconomic context and problems of today's world require the active participation of entrepreneurs, who manage innovation and boost positive changes in different spheres of society (Minello, Bürger \& Krüger, 2017; Duarte, Debona \& Perini, 2018). In this sense, entrepreneurial education is seen as one of the most efficient ways of creating and spreading entrepreneurial culture, by improving the education and performance of new entrepreneurs (Schaefer \& Minello, 2017a).

Studies on entrepreneurial education have developed significantly in the last decades due to several reasons. Among them, there is the fact that entrepreneurial education contributes to the emergence of new enterprises, to the creation of new jobs, to stimulate the economy and to the development of innovation and competitiveness in organizations in general (Lanero et. al., 2011; Lima et. al., 2015b; Siluk et. al., 2018). These results encourage engagement and innovation in thinking about the entrepreneurial activity and its influence on this evolutionary process, providing new forms of creation and dissemination of knowledge, thus presenting universities as an appropriate environment for the spreading of an entrepreneurial culture.

Tschá and Cruz Neto (2014) point out that universities contribute to the development of the "entrepreneurial culture" through "entrepreneurial education". This encourages both professors and students "to awaken inside themselves the entrepreneurial spirit and to explore their potential space for entrepreneurship, transforming realities through projects that can develop economically and socially a country and a society" (Tschá \& Cruz Neto, 2014, p. 66).

Investigating on entrepreneurial education, Filion and Lima (2010) highlighted that the entrepreneur must be prepared for action and that his characteristics and training needs require special features in the education system geared to entrepreneurial action. The authors report that, in general, university education transfers knowledge, especially the "knowhow", while entrepreneurial education "should seek to develop the knowledge of being, of knowing how to become and knowing how to take action "(Filion \& Lima, 2010, p. 46). The effectiveness of such education is directly related to the appropriate use of new methods of teaching and learning capable of educating students with knowledge and skills necessary for the entrepreneurial action (Silva \& Pena, 2017; Araújo \& Davel, 2019).

The understanding of the entrepreneurial nature and profile and how the entrepreneur expresses himself may guide actions and projects with the aim of creating environments, institutions and entrepreneurs, starting from a new proposal for entrepreneurial education (Schaefer \& Minello, 2016; Amaral, Hernandez $\&$ Bastos, 2018). For Dolabela (2008), the "entrepreneurial way of being" is related to worldview, lifestyle, leadership, reaction patterns when facing ambiguities and uncertainties, ability to make changes in yourself and in the context where you live, creation of innovation, ways and means to seek self-fulfillment.

Given these characteristics, the entrepreneur "expresses himself through a particular type of thinking and acting" (Dolabela \& Filion, 2013, p. 135): thinking as a way of seeing and understanding the world, and acting as overt behavior, coming from the first aspect. Entrepreneurship then becomes a way of being, knowing and doing, with mindset (way of thinking) and behavior (way of acting) characteristics being developed both in the students and in their professors, as individual entrepreneurs (way of being) (Schaefer, 2018).

In face of this overview and the evolution of studies on entrepreneurial education, and the characteristics of students and professors involved in it, this research aims to analyze the dimensions of the entrepreneurial mindset and behavior of undergraduate students and professors from a private institution of higher education which develops entrepreneurial education activities. 


\section{Theoretical Background}

\subsection{Entrepreneurial Education}

Entrepreneurial education has been an object of investigation of several researchers since it plays a primary role in creating and spreading entrepreneurial culture in today's society (Nabi, et. al. 2018). The entrepreneurial activity is strengthened by it, presenting itself as vital to the economy of a country. Through it, individuals are instructed and prepared with the knowledge and skills needed to perceive obstacles as opportunities, taking advantage of their situation and context to create enterprises and generate, as a consequence, economic and social development (Silva \& Pena, 2017; Duarte, Debona \& Perini, 2018).

The entrepreneurial education, however, must follow its own methodology and pedagogical approach, differing from those used in traditional education (Schaefer \& Minello, 2017a). Dolabela and Filion (2013) advocate a radical change from the traditional teaching methods, which still tend to focus on the transfer of knowledge, passing to studentcentered learning, who is able to think and act independently and proactively.

Henrique e Cunha (2008) also consider that entrepreneurial education should not be done as in other subjects, in the traditional way, and should lead students to structure contexts and to understand the various stages of their evolution. The entrepreneurial education should also focus more on the development of knowledge and sense of self and the acquisition of a know-how, far beyond the mere transmission of knowledge. Dolabela and Filion (2013) add that this new proposal of education should stimulate and develop confidence and self-esteem, seeking to immerse the student in a teaching and learning system where there is a coherent and close relationship between himself and his surrounding reality.

Mendes (2011) also argues that entrepreneurship should be treated not as an autonomous subject, as it is seen in most educational institutions, but integrated with other subjects, as there are a number of issues inherent in other research fields that intertwine in its study. The university, therefore, when willing to invest in entrepreneurial education, should do it in an integrated, interdisciplinary, harmonized and cross-curricular way. Guerra and Grazzotin (2010) also emphasize that entrepreneurship should not be discussed only in isolated subjects, and even less within the four walls of the classroom. The authors maintain that entrepreneurial education should be experienced intensely by all those involved in the process, in all directions. The professor should take the subject to the classroom in an integrated manner to other subjects, the institution and the community. "It is up to all professors the responsibility to see that students are encouraged to think and act with an entrepreneurial mindset. The classroom, increasingly, has to be transformed into a knowledge lab. The entrepreneurship issue should be treated in all courses and at all levels" (Guerra \& Grazziotin, 2010, p. 83).

In this proposal, the professor acquires new functions, starting to act more as a facilitator and a catalyst of the learning process. The students also take on a new role, as responsible for their own learning and development, motivated by their own desires and wishes that relate to their person and context. Thus, it is developed a dialectical and dialogical relationship between teacher and student during the learning process, whose profiles, thinking and action models influence each other reciprocally (Schaefer \& Minello, 2016, 2017a).

This transformation is possible, since this new approach is geared not only to students who intend to open their own businesses as individual entrepreneurs, but to all future professionals from different areas, to perform their activities and professions - individually or within organizations - with entrepreneurial values, attitudes and behavior (Lima et. al., 2015b).

The Brazil GUESSS Study Report shows that is attractive and promising that students strive to expand their vision of career possibilities. Such as being the creator of a business (with profit or social purposes), or being an entrepreneur in an autonomous or liberal profession, or being a intraentrepreneur or corporate entrepreneur, acting as an innovative employee who takes the initiative in a public or private organization. This would help educational institutions to fulfill their role

Revista de Negócios, v. 24, n. 2, p. 61-90, April, 2019. 
in a better way and students to be more active drivers of social and economic advancement (Lima et al., 2014b).

To achieve these goals, it is necessary to have new methodologies of teaching and learning that enable "learning by doing", so that the student encounters situations, challenges and difficulties that stimulate to reflect and think differently, seeking alternatives and solutions, and learning from experience. Thus, entrepreneurial education gathers actionoriented proposals for teaching and learning, such as experiential learning, learning by action, contextual learning, problem-centered learning, cooperative learning, among others (Schaefer \& Minello, 2016; Silva \& Pena, 2017, Araújo \& Davel, 2019).

The entrepreneurial training, being fostered and developed in the various dimensions of the university, leads to the concept of "entrepreneurial university". Guaranys (2010) describes that this university proposal has as its scope, in addition to teaching, research and extension, economic development, educating entrepreneurs to boost the social and economic context. The author adds that the entrepreneurial university also encourages its students from several different areas to develop entrepreneurial skills. This entrepreneurial training is coordinated and comprehensive, offered as a second area of skill development, and articulated on different fronts and projects: business incubators, technology parks, intellectual property cores articulated with research groups and laboratories, junior companies, events on entrepreneurship, actions of dissemination of entrepreneurial culture and support to social and economic enterprises in communities, among others. One is able to, therefore, "consider the entrepreneurial university a new type of university, already existing in other countries, but emerging as the most suitable alternative to the training needs of human resources and economic development in Brazil" (Guaranys, 2010, p. 105)

Presented the specificities of entrepreneurial education and training opportunities for the entrepreneur, it is then investigated the way of thinking that leads to action: the entrepreneurial mindset.

\subsection{Entrepreneurial Mindset}

A promising field of research inside the process of learning that occurs through entrepreneurial education is the entrepreneurial mindset (Schaefer \& Minello, 2017b). Filion and Lima (2010) point out that "the development of the field of entrepreneurship should be done not only for the study of entrepreneurial action, but also the entrepreneurial thinking and the links between these two concepts" (Filion \& Lima, 2010, p. 32).

Schaefer and Minello (2017b) reported that the entrepreneurial mindset has aroused the interest of authors from different areas of knowledge (administration, education, psychology, etc.) that started to conduct research with different approaches (cognitive, systemic, constructivist, ontological, humanist, etc.). Filion and Lima (2010) also emphasize that, to a greater understanding of the actions and behavior of the entrepreneur, one of the key aspects that should be better understood refers to the processes that are in the basis of his thinking, the processes from which the entrepreneurial action is primarily conceived and, in the sequence, accomplished.

Human behavior, and therefore the entrepreneurial behavior, is open, demonstrable, plastic and, through experiences and teaching strategies, new processes can be designed, trained and internalized. One way to achieve this result is to work on the representations and the thinking processes behind the entrepreneurial activity (Barini Filho, 2008).

Research on the dimensions of the modes or mental models have brought new understandings on the way that entrepreneurs impact, process and understand the contexts in which they operate, and their relationship to business performance (De Toni et. al., 2014; Dheer \& Lenartowicz, 2016; Wood et al., 2017). Studies in this area have identified mental models of entrepreneurs as a way of seeing the world, as the thought or image rooted in the mind that influence their ways of behaving and acting (De Toni et. al., 2014).

Mental models are important drivers of entrepreneurial action and entrepreneurs are directly influenced by their constituted knowledge, rational and emotional skills, view

Revista de Negócios, v. 24, n. 2, p. 61-90, April, 2019. 
of the world and of themselves shaped by their trajectory. Mental models evolve, both with life experiences and the maturing of the personality, as with learning processes promoted by education or training (De Toni et. al., 2014). Barini Filho (2008) highlights that entrepreneurs are able to abstract new rules of modeling and acting in an aligned manner with new concepts learned from experiencing a new situation or transmitted knowledge (Barini Filho, 2008).

Filion and Lima (2010) also show that it is necessary to focus the study of the entrepreneur on the act of entrepreneuring, trying to understand the model and the mental attitude that precedes the act. From images and representations of themselves and the world, entrepreneurs impact with opportunities and uncertainties the surrounding environment, project views, fulfill dreams, progressively build and shape their self-concept. The authors complement that a proper understanding of the representations of themselves and the world around them can help entrepreneurs in their way of acting and relating with the surrounding reality.

Investigating the proper mindset for a young entrepreneur to undertake a successful professional path, Mencarelli (2014) defines five dimensions of an entrepreneurial mindset or forma mentis: responsibility, autonomy, will, initiative and problem-solving spirit, and the ability to manage functional relationships with others. Table 1 describes each of these dimensions.

Table 1. Dimensions of the entrepreneurial forma mentis

\begin{tabular}{|l|l|}
\hline Dimensions & $\begin{array}{l}\text { Characteristics of the individual who } \\
\text { possesses this dimension }\end{array}$ \\
\hline Responsibility & $\begin{array}{l}\text { Asks himself about the root causes of } \\
\text { what happens, trying to harvest his } \\
\text { potential responsibilities. He is mature, } \\
\text { has a sense of responsibility and } \\
\text { constructive self-criticism and does not } \\
\text { blame external causes for the events } \\
\text { surrounding him. }\end{array}$ \\
\hline Autonomy & $\begin{array}{l}\text { He is able to act freely and } \\
\text { independently, using as reference his } \\
\text { individual criteria. Acts without being } \\
\text { influenced by people or situations, or } \\
\text { not having as necessary the support or } \\
\text { assistance from others: shows to have } \\
\text { autonomy in operation, and this is also } \\
\text { linked to self-esteem and maturity. }\end{array}$ \\
\hline He is determined, has constancy, \\
\hline
\end{tabular}

\begin{tabular}{|l|l|}
\hline & $\begin{array}{l}\text { commitment towards an individuated } \\
\text { goal. Acts in a continuous exercise of } \\
\text { his intentionality in order to fulfill his } \\
\text { projects. }\end{array}$ \\
\hline $\begin{array}{l}\text { Initiative and } \\
\text { problem- } \\
\text { solving spirit }\end{array}$ & $\begin{array}{l}\text { Knows how to be creative in the face } \\
\text { of situations, proposing suitable } \\
\text { solutions for problems. Places himself } \\
\text { in a synthetic and decisive way in front } \\
\text { of problems. Does not waste time, is } \\
\text { non-dispersive, but result-oriented. He } \\
\text { is able to recognize the priorities and to } \\
\text { adapt them in a functional response. He } \\
\text { sees the problem not as an obstacle, but } \\
\text { as an opportunity to stimulate his own } \\
\text { intelligence. }\end{array}$ \\
\hline $\begin{array}{l}\text { Ability to } \\
\text { manage } \\
\text { functional } \\
\text { relationships } \\
\text { with others }\end{array}$ & $\begin{array}{l}\text { He is able to manage relationships in a } \\
\text { functional way, that is, in advantage } \\
\text { and reference to a scope. He is able to } \\
\text { resolve a situation without controversy } \\
\text { or resort to assistentialism, but creating } \\
\text { harmony among the people functional } \\
\text { to the scope. He is able to manage the } \\
\text { relations in an intelligent and } \\
\text { diplomatic way. }\end{array}$ \\
\hline
\end{tabular}

Source: Adapted from Mencarelli (2014).

These dimensions of entrepreneurial mindset or forma mentis identified and described by Mencarelli (2014) will be used for the analysis of the research data, as it will be detailed in the methodological procedures.

Having described the aspects of the entrepreneurial mindset, we continue to describe how this way of thinking defines the way of acting through the entrepreneurial behavior.

\subsection{Entrepreneurial Behavior}

Different studies have been conducted in the last decades to describe the entrepreneur under the behavioral perspective, as well as reviews and compilations of the evolution of these studies (Barini Filho, 2008; Coan, 2011; Krüger, 2019). The study of the entrepreneurial activity has attracted the attention of researchers from different fields. Not just administrators or economists, but educators, sociologists, psychologists and researchers in the fields of exact sciences began to investigate the way of thinking and acting of entrepreneurs. This melting pot of theoretical and methodological approaches - each with its paradigms, research methods, analysis patterns, experiences, contents, etc. - could not generate but different views on the concept, enriching the 
understanding of this field of study. Dolabella (2008, p. 78) points out that "this new look on the entrepreneurial capacity transported it from its original cradle, the company - without leaving it, - to all human activities".

Ribas (2011) also emphasizes that the entrepreneurial behavior has to be investigated by researchers from different areas of expertise, who began studying the "accomplishing behavior of the entrepreneur". This behavior is the obverse of conformity with the status quo, of the search for security and stability, of opposition to change, characteristics of most people. "On the contrary, the entrepreneur reflects this concern by creating, by making it happen, by enjoying a condition of being the center and not part, even at the risk of losing everything and become nothing" (Ribas, 2011, p. 37).

The entrepreneurial behavior comprises the features that some individuals exhibit, how they perceive entrepreneurial opportunities, how they think and process, how they adapt, how they are predisposed to action, at last how they act in an entrepreneurial way (Hisrich, Peters \& Shepherd, 2014). These features are unfolded in the view of Minello (2014, p. 74), who understands the entrepreneur as "the individual who develops something new, has initiative, ability to organize and reorganize social and economic mechanisms to turn resources and situations to practical advantage, and accepts the risk or failure of his actions" (Minello, 2014, p. 74).

For Dolabela (2008), being an entrepreneur is to not only accumulate knowledge, but to possess and demonstrate attitudes, ways of perceiving the world and yourself, behaviors, it is to turn to activities where there is a risk and the possibility to innovate, to persevere, to live with uncertainty. Tschá and Cruz Neto understand the entrepreneur as a critical agent who recognizes and assumes the power to create and transform, inherent of the human being. Performing these capabilities, he places himself as "a reality changer agent (as a solver of problems that afflict society) through collaborative ventures which he develops" (Tschá \& Cruz Neto, 2014, p. 70). This way, the entrepreneur, in order to be considered as such, cannot be dissociated from the entrepreneuring action, strongly driven by the motivation of accomplishment.

In relation to this aspect of entrepreneurial behavior, David McClelland (1972, 1978, 1987) gained prominence with his studies that investigated the motivation for entrepreneurship associated to the need of accomplishment. The author carried out research for nearly five decades and in different countries and cultures, studying the behavioral aspects of entrepreneurs, especially related to the motivation to take their actions. The researcher perceived entrepreneurs as different individuals and began to investigate their main behavioral characteristics, so that it was possible to create programs to stimulate the development of these characteristics (Matias \& Martins, 2012).

Lima and Nassif (2017, p. 370) point out that McClelland's theory figures "as one of the most referred to in the literature on entrepreneurs presenting needs as a motivator factor for the individual. This author developed a model that has been used in the theoretical basis of training for entrepreneurs". Dedicating his life to the study of entrepreneurial behavior, McClelland sought to identify personal characteristics inherent to the successful entrepreneur. His studies contributed to the formatting of the Empretec, a program developed globally by the United Nations (UN) in the 80s and, from his studies, programs have been created to project the development of entrepreneurial behavior in different countries (Krüger, Pinheiro \& Minello, 2017).

For McClelland (1972), therefore, the success of individuals, groups or even a nation is in motivation, which may result from three dominant needs: achievement, power and affiliation. McClelland (1972, 1978, 1987) observed that the normal human being has a predominant profile of needs - for achievement, affiliation or power - to a greater or lesser extent influence on his behavior and interaction with the surrounding environment. The researcher also found that people with the greatest need for achievement are more likely to become entrepreneurs and that these skills can be stimulated and developed through specific training programs, obtaining with these individuals the same success obtained by those who developed these characteristics innately. This way, the author advanced in his studies, dedicating himself in the understanding of these

Revista de Negócios, v. 24, n. 2, p. 61-90, April, 2019. 
competences, named "characteristics of the entrepreneurial behavior" (Matias \& Martins, 2012; Krüger, Pinheiro \& Minello, 2017).

These characteristics of the entrepreneurial behavior were later grouped into three broad categories (accomplishment, planning and power) and are described in Table 2.

Table 2. Characteristics of the entrepreneurial behavior

\begin{tabular}{|c|c|c|}
\hline Cat. & Charact. & Behavior \\
\hline \multirow{5}{*}{ 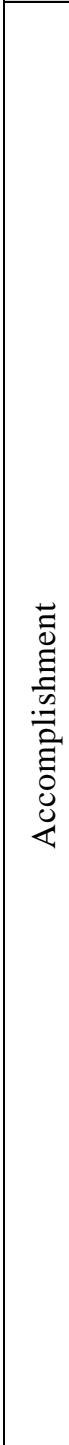 } & $\begin{array}{l}\text { Search for } \\
\text { opportuni- } \\
\text { ties and } \\
\text { initiative }\end{array}$ & $\begin{array}{l}\text { Does things before asked, or before } \\
\text { being forced by circumstances; acts } \\
\text { to expand the business into new } \\
\text { areas, products or services; takes } \\
\text { advantage of unusual opportunities to } \\
\text { start a business, to obtain financing, } \\
\text { equipment, land, workplace or } \\
\text { assistance. }\end{array}$ \\
\hline & $\begin{array}{l}\text { Taking } \\
\text { calculated } \\
\text { risks }\end{array}$ & $\begin{array}{l}\text { Evaluates alternatives and calculates } \\
\text { risks deliberately; acts to reduce the } \\
\text { risks or to control the outcomes; puts } \\
\text { himself in situations involving } \\
\text { challenges or moderate risks. }\end{array}$ \\
\hline & $\begin{array}{l}\text { Persistenc } \\
\mathrm{e}\end{array}$ & $\begin{array}{l}\text { Acts before a meaningful obstacle; } \\
\text { acts repeatedly or changes strategy in } \\
\text { order to face a challenge or overcome } \\
\text { an obstacle; makes a personal } \\
\text { sacrifice or performs an extraordinary } \\
\text { effort to complete a task. }\end{array}$ \\
\hline & $\begin{array}{l}\text { Demand } \\
\text { for quality } \\
\text { and } \\
\text { efficiency }\end{array}$ & $\begin{array}{l}\text { Finds ways to do things better, faster } \\
\text { or cheaper; acts in a way to do things } \\
\text { that meet or exceed standards of } \\
\text { excellence; develops or uses } \\
\text { procedures to ensure that work is } \\
\text { completed in time, or that the work } \\
\text { meets quality standards previously } \\
\text { agreed. }\end{array}$ \\
\hline & Commitment & $\begin{array}{l}\text { Takes personal responsibility for the } \\
\text { performance necessary to the } \\
\text { achievement of goals and objectives; } \\
\text { collaborates with employees or puts } \\
\text { himself in their place, if necessary, to } \\
\text { finish a job; strives to keep customers } \\
\text { happy and puts in first place the good } \\
\text { will in the long run, rather than short- } \\
\text { term profit. }\end{array}$ \\
\hline \multirow[t]{2}{*}{$\begin{array}{l}\stackrel{\infty}{\Xi} \\
\stackrel{\Xi}{\Xi} \\
\frac{\Xi}{a}\end{array}$} & $\begin{array}{l}\text { Search for } \\
\text { infor- } \\
\text { mation }\end{array}$ & $\begin{array}{l}\text { Dedicates personally to obtain } \\
\text { information from customers, } \\
\text { suppliers and competitors; personally } \\
\text { investigates how to manufacture a } \\
\text { product or provide a service; consults } \\
\text { experts for technical or commercial } \\
\text { advisory. }\end{array}$ \\
\hline & $\begin{array}{l}\text { Setting of } \\
\text { goals }\end{array}$ & $\begin{array}{l}\text { Establishes goals and objectives that } \\
\text { are challenging and that have } \\
\text { personal meaning; sets clear and } \\
\text { specific long-term goals; establishes } \\
\text { measurable and short-term goals. }\end{array}$ \\
\hline
\end{tabular}

\begin{tabular}{|c|c|c|}
\hline & $\begin{array}{l}\text { Systematic } \\
\text { planning } \\
\text { and } \\
\text { monitorin } \\
\text { g }\end{array}$ & $\begin{array}{l}\text { Plans dividing large tasks into sub- } \\
\text { tasks with deadlines; constantly } \\
\text { reviews plans, taking into account the } \\
\text { achieved results and circumstantial } \\
\text { changes; keeps financial records and } \\
\text { uses them to make decisions. }\end{array}$ \\
\hline \multirow[b]{2}{*}{$\begin{array}{l}\dot{0} \\
3 \\
0 \\
0\end{array}$} & $\begin{array}{l}\text { Persuasion } \\
\text { and } \\
\text { contact } \\
\text { networks }\end{array}$ & $\begin{array}{l}\text { Uses deliberate strategies to influence } \\
\text { or persuade others; uses key people } \\
\text { as agents to achieve his own goals; } \\
\text { acts to develop and maintain business } \\
\text { relations. }\end{array}$ \\
\hline & $\begin{array}{l}\text { Indepen- } \\
\text { dence and } \\
\text { self- } \\
\text { confidence }\end{array}$ & $\begin{array}{l}\text { Searches for autonomy in relation to } \\
\text { rules and controls of others; } \\
\text { maintains his point of view in the } \\
\text { face of opposition or initially } \\
\text { disappointing results; expresses } \\
\text { confidence in his own ability to } \\
\text { complete a difficult task or face a } \\
\text { challenge. }\end{array}$ \\
\hline
\end{tabular}

Fonte: Adapted from MSI (1990).

These characteristics of the entrepreneurial behavior identified and described by McClelland (Mansfield et al., 1987; MSI, 1990) will be used for the analysis of this research data, as it will be detailed in the sequence.

Having described the entrepreneurial nature and how it manifests itself in the entrepreneur, through his mindset and behavior, we continue to the methodological procedures adopted in this research.

\section{Methodological procedures}

Based on the objective set for this article, this theoretical and empirical research presents a quantitative approach, of the descriptive type. This type of research aims to obtain information about a particular population objectively, allowing the quantification of data, using statistical data, numbering and evaluating this data (Oliveira, 2002; Roesch, 2005). The use of quantitative methods for analysis of the social reality present in the same study or separated into different studies aims to describe and/or compare characteristics of social groups, contexts, situations or institutions, establishing causal relationships (Ramos, 2013).

In this study, the data collection was carried out in a private higher education institution in Rio Grande do Sul - Brazil, which has activities and projects that characterize an entrepreneurial university, as described by 
Guaranys (2010). Data were collected with professors and students from the three undergraduate courses with more students (Business Administration, Law and Information Systems), all with cross-curricular subjects of entrepreneurial education.

Initially, an informal survey was conducted (Triviños, 2008; Yin, 2016) with students of the educational institution, in order to identify the professors who, in the view of students, perform unique and innovative activities. The informal survey sought to identify who the professors are, what they do, and the achieved results. It was stipulated as a goal to interview $40 \%$ of each of the three courses of the institution, as they were found circulating in the institution, either in the breaks between classes, hallways or coffee shop. Out of 427 undergraduate students, 170 attended the informal data gathering. From the analysis of data collected by the informal survey, four professors were identified as most cited in each of the three courses of the analyzed institution of higher education. A total of 12 professors, who participated in the second quantitative moment of the research, described in the next paragraphs, besides a qualitative continuity of the research, with semi-structured interviews and data triangulation on entrepreneurial education (Schaefer, 2018), which is not being focused in this article.

The second moment of the methodological approach used two instruments for data collection. The first refers to McClelland's entrepreneurial behavioral characteristics (EBC's) (Mansfield et al., 1987; MSI, 1990), in order to identify the entrepreneurial behavior of students and professors. The second corresponds to the Forma mentis questionnaire (Mencarelli, 2014), which measures 5 dimensions of the entrepreneurial mindset. For the population of 427 students of the institution, the minimum sample was calculated based on Hair et al. (2005), which was considered a nonprobabilistic sampling by convenience, taking into account the number of variables of the applied instruments. For the treatment and analysis of collected data, statistical tests were performed. Figure 1 shows schematically the methodological procedures of the study.
Figure 1. Methodological research procedures

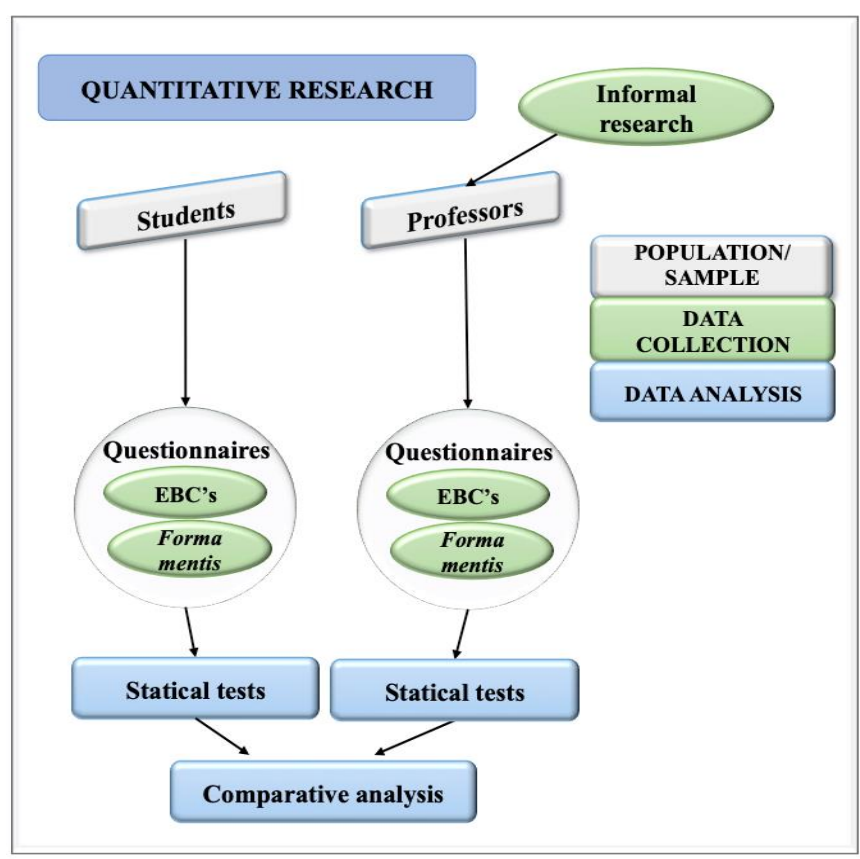

Source: prepared by the authors.

McClelland's questionnaire of EBCs (Mansfield et al., 1987; MSI, 1990) consists of 55 statements and was developed from the original research studies of McClelland (McClelland, 1972, 1978, 1987). Respondents can assign a value from one to five, in a Likert scale. The 10 dimensions of the EBCs are evaluated by means of respective questions, as shown in Table 3 .

Table 3. Dimensions and questions of the instrument of McClelland's EBCs

\begin{tabular}{|c|c|c|c|c|c|}
\hline Dimensions & \multicolumn{5}{|c|}{ Questions } \\
\hline $\begin{array}{l}\text { Search for } \\
\text { opportunities and } \\
\text { initiative }\end{array}$ & Q1 & Q12 & Q23 & $\begin{array}{c}\mathrm{Q} 34 \\
*\end{array}$ & Q45 \\
\hline Persistence & Q2 & Q13 & Q24 & $\begin{array}{c}\mathrm{Q} 35 \\
*\end{array}$ & $\mathrm{Q} 46$ \\
\hline Commitment & Q3 & Q14 & Q25 & Q36 & $\begin{array}{c}\text { Q47 } \\
*\end{array}$ \\
\hline $\begin{array}{l}\text { Demand for quality } \\
\text { and efficiency }\end{array}$ & $\mathrm{Q} 4$ & Q15 & Q26 & Q37 & Q48 \\
\hline $\begin{array}{l}\text { Taking calculated } \\
\text { risks }\end{array}$ & Q5 & Q16 & Q27 & $\begin{array}{c}\mathrm{Q} 38 \\
*\end{array}$ & Q49 \\
\hline Setting goals & Q6 & $\begin{array}{c}\mathrm{Q} 17 \\
*\end{array}$ & Q28 & Q39 & Q50 \\
\hline $\begin{array}{l}\text { Search for } \\
\text { information }\end{array}$ & Q7 & Q18 & Q29* & Q40 & Q51 \\
\hline $\begin{array}{l}\text { Systematic planning } \\
\text { and monitoring }\end{array}$ & Q8 & Q19 & Q30 & $\begin{array}{c}\mathrm{Q} 41 \\
*\end{array}$ & Q52 \\
\hline $\begin{array}{l}\text { Persuasion and } \\
\text { contact networks }\end{array}$ & Q9 & $\begin{array}{c}\mathrm{Q} 20 \\
*\end{array}$ & Q31 & Q42 & Q53 \\
\hline
\end{tabular}




\begin{tabular}{|l|c|c|c|c|c|}
\hline $\begin{array}{l}\text { Independence and } \\
\text { self-confidence }\end{array}$ & Q10 & $\begin{array}{c}\text { Q21 } \\
*\end{array}$ & Q32 & Q43 & Q54 \\
\hline
\end{tabular}

* Negative questions.

Source: Created by the authors, based on Mansfield (1987).

In this context, $(*)$ corresponds to negative questions, which the score must be subtracted from the final result of the respective characteristic and 6 points should be added at the end of the sum. Questions of numbers 11, 22, 33, 44 and 55 correspond to the "Correction Factor" used to prevent, often unconsciously, the respondent presents an overly favorable selfimage. The Correction Factor is used if the score of the sum of these questions is equal or greater than 20 points. If this occurs, all EBCs should be corrected by subtracting the corresponding points as shown in Table 4.

Table 4. Correction factor for the questionnaire of McClelland's EBCs

\begin{tabular}{|c|c|}
\hline $\begin{array}{c}\text { If the total of points for the } \\
\text { Correction Factor is } \ldots\end{array}$ & $\begin{array}{c}\text {... subtract the number } \\
\text { below from the score }\end{array}$ \\
\hline 24 or 25 & 7 \\
\hline 22 or 23 & 5 \\
\hline 20 or 23 & 3 \\
\hline 19 or less & 0 \\
\hline
\end{tabular}

Source: Created by the authors, based on Mansfield (1987).

The final score after applying the Correction Factor identifies the intensity of each of the ten entrepreneurial behavioral characteristics. The maximum score is 25 points for each characteristic.

To analyze the entrepreneurial mindset of professors and students participating in the research, the Forma mentis questionnaire, developed by Mencarelli (2014), was applied along with the EBCs questionnaire. The instrument consists of 62 questions with three alternatives each, related to the five dimensions of the entrepreneurial mindset: autonomy, responsibility, will, spirit of initiative and problem solving, and the ability to manage functional relationships with the group. These five dimensions are evaluated through respective questions, which seek to identify the appropriate forma mentis for each given situation. The five dimensions are evaluated by means of respective questions, as shown in Table 5.

Table 5. Dimensions and questions of the Forma mentis questionnaire

\begin{tabular}{|l|c|c|c|c|c|c|}
\hline Dimensions & \multicolumn{7}{|c|}{ Questions } \\
\hline \multirow{2}{*}{ Autonomy } & Q32 & Q34 & Q36 & Q39 & Q41 & Q42 \\
\cline { 2 - 7 } & Q49 & Q52 & Q53 & Q56 & Q57 & \\
\hline \multirow{3}{*}{ Responsibility } & Q9 & Q19 & Q21 & Q22 & Q24 & Q25 \\
\cline { 2 - 7 } & Q28 & Q30 & Q33 & Q37 & Q43 & Q44 \\
\cline { 2 - 7 } & Q46 & Q47 & Q54 & Q61 & & \\
\hline \multirow{2}{*}{ Will } & Q1 & Q2 & Q3 & Q4 & Q5 & Q8 \\
\hline $\begin{array}{l}\text { Initiative and } \\
\text { problem- } \\
\text { solving spirit }\end{array}$ & Q6 & Q11 & Q14 & Q29 & Q50 & Q62 \\
\cline { 2 - 7 } & Q23 & Q26 & Q27 & Q40 & Q51 & Q18 \\
\hline $\begin{array}{l}\text { Ability to keep } \\
\text { functional } \\
\text { relationships }\end{array}$ & Q7 & Q13 & Q15 & Q31 & Q35 & Q38 \\
\cline { 2 - 7 } & Q45 & Q48 & & & & \\
\hline
\end{tabular}

Source: Created by the authors, based on Mencarelli (2014).

The data from both questionnaires were tabulated in an electronic spreadsheet, which enabled the organization and processing of the numerical data, following the guidelines of the authors of each instrument to verify or not the existence of entrepreneurial behavior characteristics in the respondents and evaluate the intensities of the entrepreneurial mindset dimensions.

For the processing and analysis of data, statistical tests were performed using the SPSS software. On this occasion were analyzed quantitatively and exploited the data of the models proposed by McClelland (Mansfield et al., 1987; MSI, 1990) and Mencarelli (2014).

For each instrument it was calculated the means, the intensity and standard deviation of each characteristic, dimension and constructs studied. Then, to estimate reliability, the internal consistency was measured by Cronbach's Alpha Coefficient (Sampieri, Collado \& Lucio, 2013).

In order to establish the relationship between the entrepreneurial behavioral characteristics and the dimensions of the entrepreneurial mindset, we used the Pearson Correlation Coefficient, a parametric technique that indicates the measure of the strength of association between two variables (Collis \& Hussey, 2005) . To evaluate the correlation between the results of entrepreneurial behavioral characteristics and dimensions of the

Revista de Negócios, v. 24, n. 2, p. 61-90, April, 2019. 
entrepreneurial mindset of professors and students, the Mann-Whitney test was performed. This test is used to compare the positions between the two groups, verifying if the two populations have the same distribution, indicating equality in behavior (Lopes, 2016).

The analysis of the results of this research is presented next.

\section{Analysis of results}

The analysis of the results will be presented in three steps: initially, the results of the instruments applied to professors, then the analysis of the results of the students and, finally, we analyze the relations of the quantitative data of professors and students, crossing entrepreneurial behavioral characteristics and mindset in order to identify possible similarities and discrepancies.

\subsection{Analysis of professors}

The collection instruments adopted by this research were answered by the 12 professors most referenced by students in the informal survey, whose profile is shown in Table 6 .

Table 6. Sample characteristics - professors

\begin{tabular}{|c|c|c|c|}
\hline \multirow[t]{2}{*}{ Category } & \multirow[t]{2}{*}{ Variables } & \multicolumn{2}{|c|}{ Frequency } \\
\hline & & Absolute & $\%$ \\
\hline \multirow[t]{2}{*}{ Sex } & Male & 8 & 66.67 \\
\hline & Female & 4 & 33.33 \\
\hline \multirow[t]{2}{*}{ Marital status } & Married (a) & 4 & 33.33 \\
\hline & Single (a) & 8 & 66.67 \\
\hline \multirow{2}{*}{$\begin{array}{l}\text { Had } \\
\text { entrepreneurial } \\
\text { training at under- } \\
\text { graduation level }\end{array}$} & Yes & 10 & 83.33 \\
\hline & No & 2 & 16.67 \\
\hline \multirow{2}{*}{$\begin{array}{l}\text { Has or had an } \\
\text { entrepreneurial } \\
\text { activity }\end{array}$} & Yes & 12 & 100.0 \\
\hline & No & 0 & 0.00 \\
\hline Category & Parameters & \multicolumn{2}{|c|}{ Values } \\
\hline \multirow[t]{3}{*}{ Age } & Min. & \multicolumn{2}{|c|}{30} \\
\hline & Max. & \multicolumn{2}{|c|}{44} \\
\hline & Average & \multicolumn{2}{|c|}{35.5} \\
\hline
\end{tabular}

Source: created by the authors.

The analysis of the results began with the calculation of minimum, maximum, means and standard deviation for each EBC and entrepreneurial mindset dimension of the investigated professors, portrayed in Table 7.
Table 7. Descriptive statistics - professors

\begin{tabular}{|c|c|c|c|c|c|}
\hline & $\begin{array}{c}\text { Characteristic/ } \\
\text { Dimension }\end{array}$ & Min & $\operatorname{Max}$ & $\begin{array}{l}\text { Mean } \\
\text { value }\end{array}$ & SD \\
\hline \multirow{10}{*}{$\sum_{-\infty}^{\infty}$} & $\begin{array}{l}\text { Search for } \\
\text { opportunities and } \\
\text { iniciative }\end{array}$ & 18 & 24 & 20.500 & 1.930 \\
\hline & Persistence & 15 & 22 & 17.916 & 1.831 \\
\hline & Commitment & 19 & 24 & 21.083 & 1.240 \\
\hline & $\begin{array}{l}\text { Demand for } \\
\text { quality and } \\
\text { efficiency }\end{array}$ & 17 & 22 & 20.166 & 1.749 \\
\hline & $\begin{array}{l}\text { Taking calculated } \\
\text { risks }\end{array}$ & 15 & 21 & 17.500 & 1.623 \\
\hline & $\begin{array}{l}\text { Setting of } \\
\text { goals }\end{array}$ & 16 & 24 & 20.500 & 2.467 \\
\hline & $\begin{array}{l}\text { Search for } \\
\text { information }\end{array}$ & 17 & 25 & 20.916 & 2.712 \\
\hline & $\begin{array}{l}\text { Systematic } \\
\text { planning and } \\
\text { monitoring }\end{array}$ & 17 & 25 & 19.833 & 2.552 \\
\hline & $\begin{array}{l}\text { Persuasion and } \\
\text { networks }\end{array}$ & 13 & 23 & 18.083 & 2.644 \\
\hline & $\begin{array}{l}\text { Independence and } \\
\text { self-confidence }\end{array}$ & 17 & 22 & 19.583 & 1.729 \\
\hline \multirow{5}{*}{ 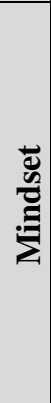 } & Autonomy & 8 & 13 & 9.916 & 1.240 \\
\hline & Responsibility & 9 & 16 & 13.833 & 1.946 \\
\hline & Will & 7 & 12 & 9.666 & 1.497 \\
\hline & $\begin{array}{l}\text { Initiative and } \\
\text { problem-solving } \\
\text { spirit }\end{array}$ & 7 & 11 & 8.666 & 1.435 \\
\hline & $\begin{array}{l}\text { Ability to have } \\
\text { functional } \\
\text { relationships }\end{array}$ & 3 & 8 & 5.750 & 1.422 \\
\hline
\end{tabular}

Source: Created by the authors

Regarding the entrepreneurial behavioral characteristics, the maximum limit is 25 points, reached in the characteristics search for information and systematic planning and monitoring, and the minimum limit of 5 points, not verified in any characteristic. A minimum score below 15 points, which for McClelland indicates the absence of the characteristic (Mansfield et al., 1987), was found only in the characteristic persuasion and networks (13 points), indicating that one or more professors do not possess this characteristic. In the case of mindset, each dimension has its own maximum limit, which varies according to the number of questions for each dimension, as described in the methodological procedures. The maximum limit was reached in four dimensions: autonomy (13 points), responsibility (16 points), will (12 points)

Revista de Negócios, v. 24, n. 2, p. 61-90, April, 2019. 
and functional relations with the group (8 points). The minimum limit of this instrument is the absence of points, not seen in any of the mindset dimensions. The smallest standard deviation was found in the EBC commitment characteristic and in the mindset autonomy dimension.

Using the minimum score of 15 points, all professors investigated in this study may be considered entrepreneurs according to the questionnaire of entrepreneurial behavioral characteristics (Mansfield et. al., 1987), as shown in Figure 2.

Figure 2. Distribution of means of EBCs - professors

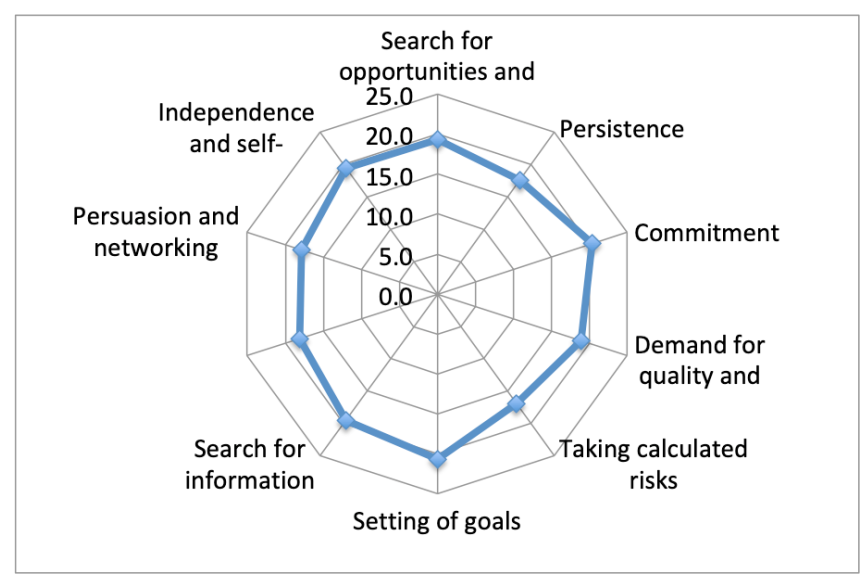

Source: Created by the authors.
However, for this study, it was decided to adopt a stratification to analyze the intensity of EBCs of the participants, with the objective of better understanding their characteristics. Thus, it was adopted a stratification dividing the total score, ranking it in intensity levels: Nonexistent, Low, Medium and High. For a better visualization of the data with this stratification, we used a complementary color scale as follows: Non-existent below 15 points (gray), Low from 15 to 18.3 points (orange), Medium from 18.4 to 21.7 points (yellow), and High from 21.7 to 25 points (green) as shown in Figure 3.

Figure 3. Stratification of the EBCs levels

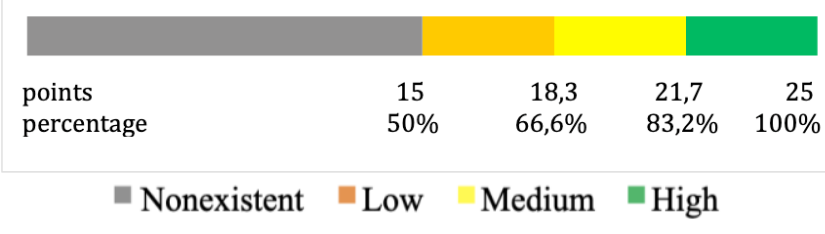

Source: created by the authors

From this scale, Figure 4 shows the mean value of each dimension of the entrepreneurial behavioral characteristics verified in the professors.

Figure 4. Mean values of entrepreneurial behavioral characteristics - professors

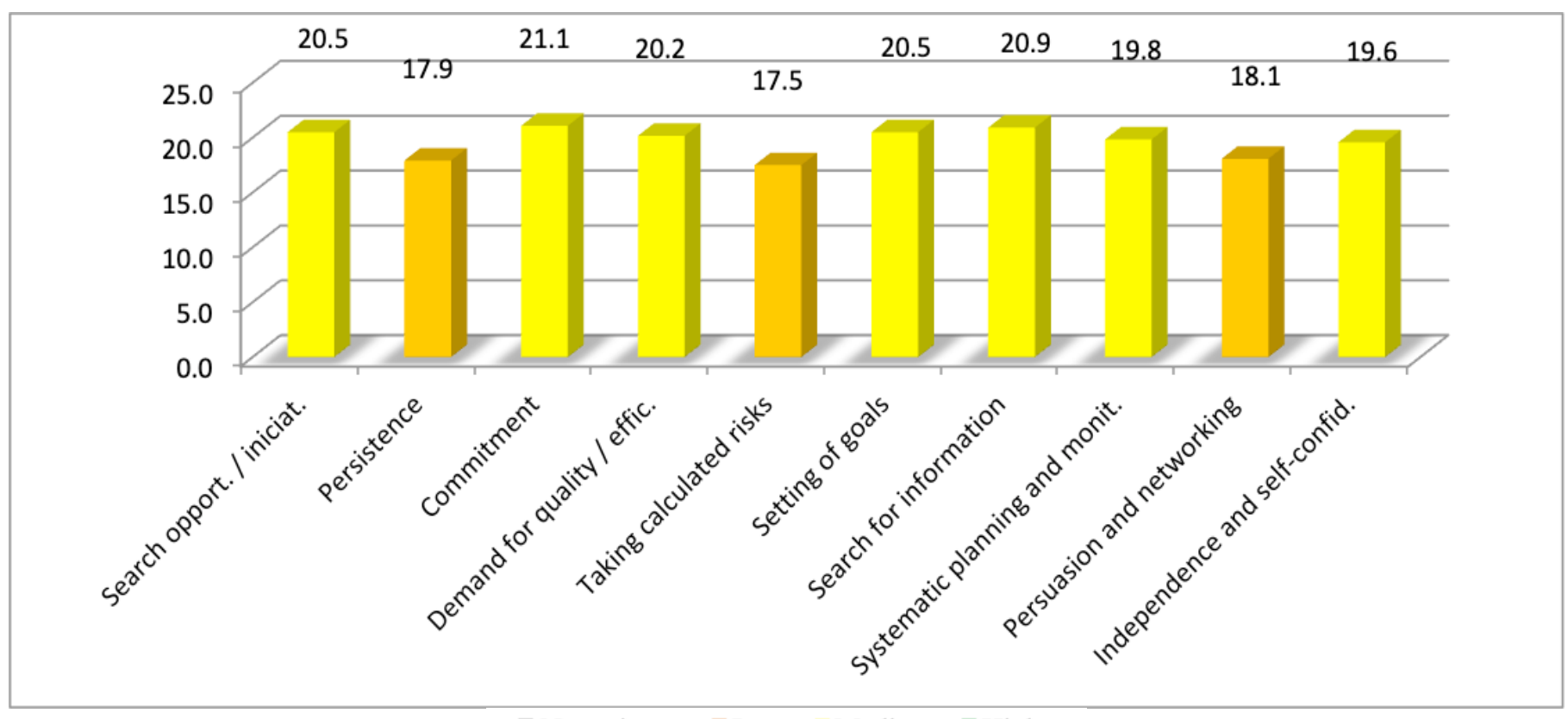

Source: created by the authors.

Revista de Negócios, v. 24, n. 2, p. 61-90, April, 2019. 
From the mean values, it may be inferred that the surveyed professors have the ten entrepreneurial behavioral characteristics (15 points or more), 7 of them are characterized as of medium intensity: search for opportunities and initiative, commitment, demand for quality and efficiency, setting of goals, search for information, systematic planning and monitoring and independence and selfconfidence. The other three characteristics have low intensity: persistence, taking calculated risks, and persuasion and networking. The characteristic with the highest mean value was commitment, with 21.1 points, and the one with the lowest value was taking calculated risks, with 17.5 points.

To better understand this data, it was performed the calculation of the percentages of the intensities of each behavioral characteristic shown in Figure 5.

It is possible to verify the percentage of respondents before each entrepreneurial behavioral characteristic. The characteristic with the highest mean value, commitment (21.1 points), has a better distribution of intensity: $75 \%$ of professors have this characteristic with medium intensity and $25 \%$ with high intensity. Commitment is related to personal sacrifice and effort above average to perform a job (MSI, 1990). It can be inferred, from these results, that the professors investigated take personal responsibility for the performance necessary for the achievement of goals, collaborating with those involved for the implementation of work, so that the objective is reached.

The behavioral characteristic with the

Figure 5. Intensity of entrepreneurial behavioral characteristics - professors

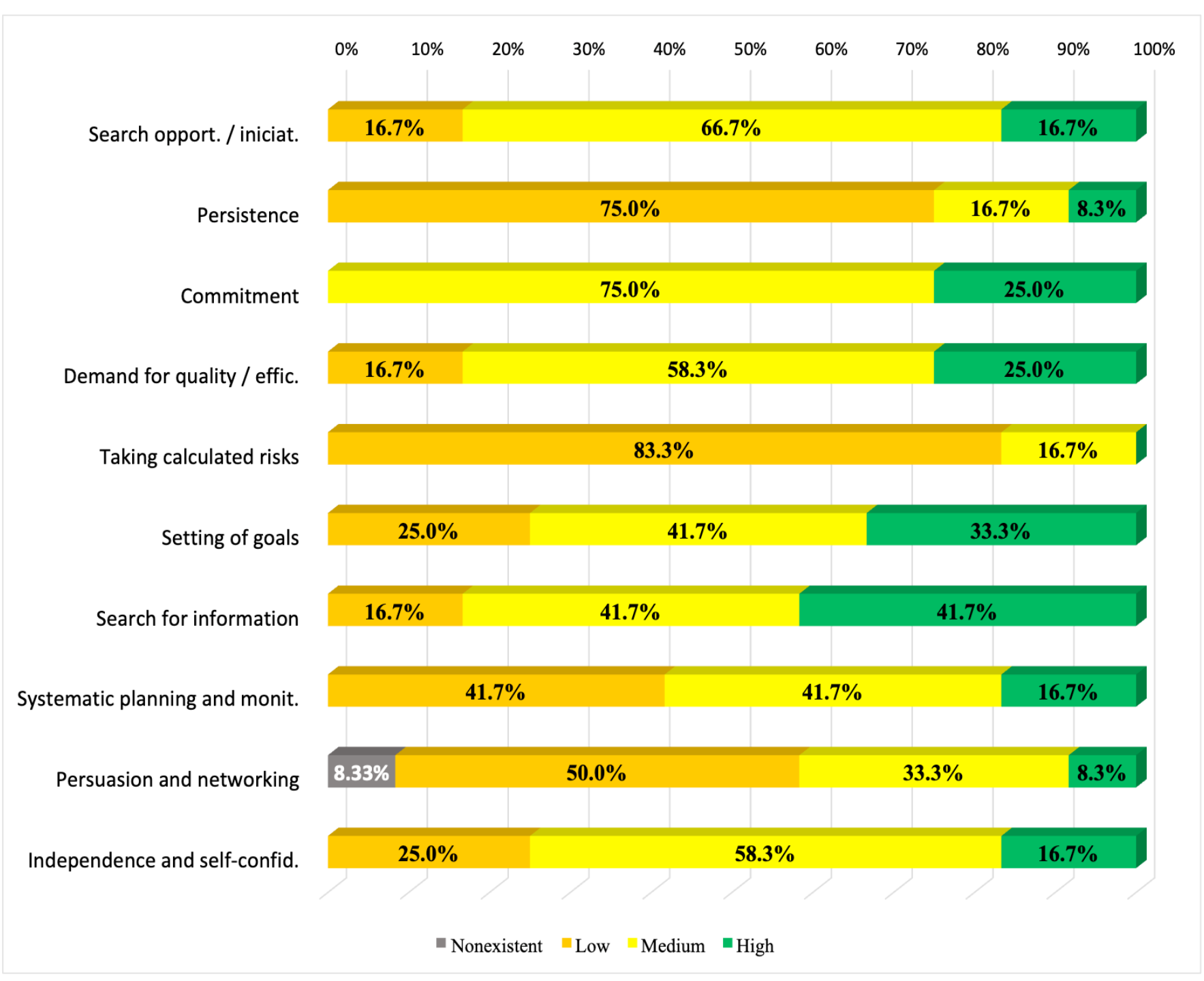

Source: created by the authors.

Revista de Negócios, v. 24, n. 2, p. 61-90, April, 2019. 
highest percentage of high intensity is the search for information, corresponding to $41.7 \%$ of professors. This feature is related to the individual who personally dedicates himself to obtain information from customers, suppliers, competitors and others involved with the activity and project with which he is involved (MSI, 1990). Making use of personal and business contacts to get useful information and resources, professors can increment and intensify their entrepreneurial education projects, strengthening the link between education and the real market world.

The characteristic with the lowest average is taking calculated risks (17.5 points), with the following distribution: $83.3 \%$ of professors have low intensity and $16.7 \%$ medium intensity. This feature, which should be developed in professors, taking into account of all the results, is related to the individual who evaluates and calculates risks deliberately, takes attitudes to reduce the risks or to control the outcomes (MSI, 1990). Based on this result, professors can be encouraged to put themselves in situations involving challenges or moderate risk, present in every enterprise, so that this characteristic is intensified.

The only characteristic that showed a percentage of professors with nonexistent intensity was persuasion and networking $(8.33 \%)$. It is inferred from this that this professor does not use deliberate strategies to influence or persuade others. This characteristic may be intensified so that key people can be used as agents to achieve his own objectives (MSI, 1990).

Next, Figure 6 shows the mean values of the dimensions of entrepreneurial mindset for professors, measured by the Forma mentis test (Mencarelli, 2014), with the points obtained for each dimension and missing points to the maximum limit, considering that the limit varies for each dimension, as described in the section on methodological procedures. It can be seen in the figure that the highest proportional average among the dimensions of professors' mindset is responsibility (13.8 points obtained out of 16) and the lowest is the spirit of initiative and problem solving (8.7 points obtained out of 13).
Figure 6. Mean value of dimensions of entrepreneurial mindset - professors

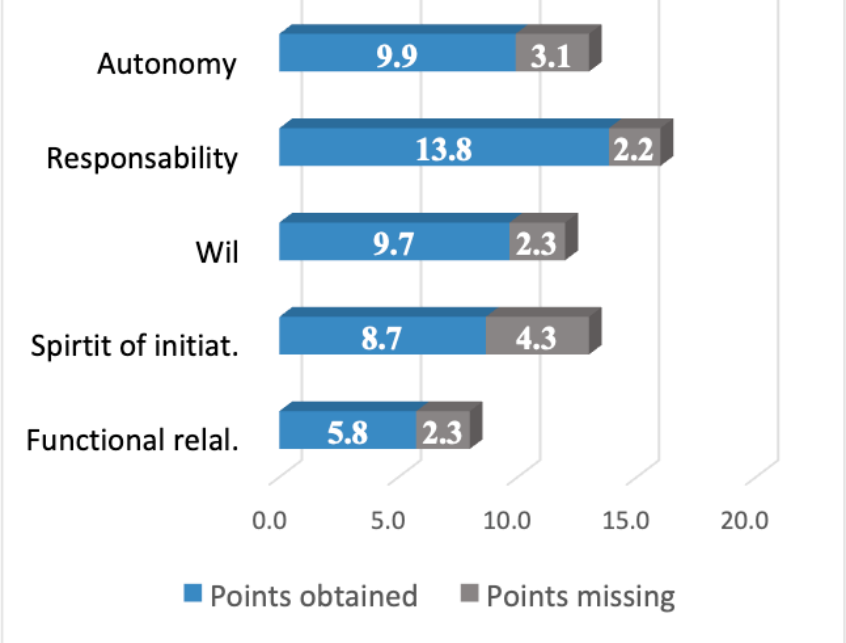

Source: created by the authors.

Figure 7 shows the average of each dimension of the entrepreneurial mindset in the faculty members. In order to facilitate the reading, a color stratification has been established, being orange for low intensity, yellow for medium intensity and green for high intensity.

Figure 7. Intensity of the mean values of the entrepreneurial mindset dimensions - Professors

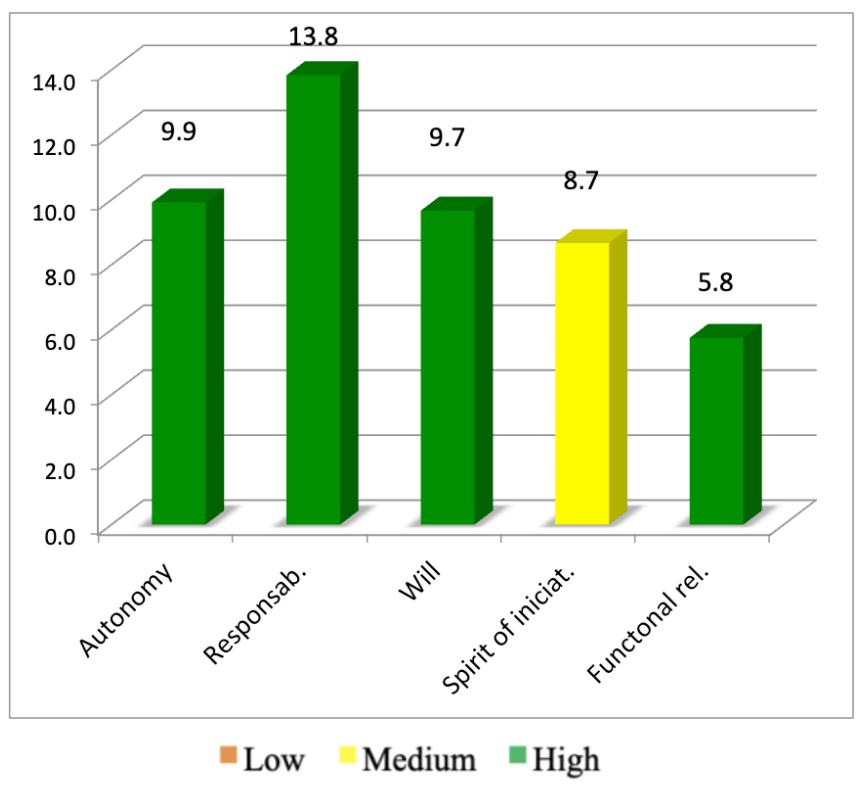

Source: created by the authors.

According to Figure 7 , out of the mean values of the 5 dimensions, 4 of them presented high intensity: autonomy (9.9points out of 13), responsibility (13.8 points out of 16$)$, will (9.7

Revista de Negócios, v. 24, n. 2, p. 61-90, April, 2019. 
points out of 12), and ability to manage functional relationships (5.8 points out of 8 ). One of them, spirit of initiative and problem solving showed medium intensity (8.7 points out of 13 ). Then, it was calculated the intensities of the dimensions of entrepreneurial mindset in the professors, reported in Figure 8.

It is possible to verify the percentage of respondents on each dimension of entrepreneurial mindset. It is inferred that the 12 investigated professors showed high or medium intensities for mindset dimensions, and none showed any dimension with low intensity. The dimension with the highest percentage of professors with high intensity was responsibility, with $83.3 \%$. This dimension refers to the attitude of asking yourself about the root causes of what happens in order to identify and take responsibility for your potential liabilities. From these results, it can be inferred that the investigated professors have a sense of responsibility and constructive self-criticism, they are mature and do not blame external things for faults or causes of events with which they are involved (Mencarelli, 2014).

The only dimension in which the percentage of professors with medium intensity $(58.3 \%)$ exceeded high intensity $(41.7 \%)$ was spirit of initiative. This dimension characterizes an individual who knows how to be creative facing situations, proposing suitable solutions to problems. An individual with entrepreneurial mindset with this dimension also places himself facing problems in a synthetic and resolving manner, does not waste time nor is dispersive, being oriented towards results (Mencarelli, 2014). The professors investigated in this research can develop more this dimension of mindset in order to strengthen the ability to recognize the priorities and adapt them in a functional response to the context, seeing the problem not as an obstacle, but as an opportunity to stimulate his own intelligence.

To estimate the reliability, the internal consistency was measured by Cronbach's alpha (Sampieri, Collado \& Lucio, 2013; Lopes, 2016). Cronbach's alpha is calculated through the following equation:

$$
\alpha=\frac{\mathrm{k}}{(\mathrm{k}-1)}\left[1-\frac{\sum_{\mathrm{j}=1}^{\mathrm{n}} \mathrm{S}_{\mathrm{j}}^{2}}{\mathrm{~S}_{\mathrm{T}}^{2}}\right]
$$

where:

$\mathrm{k}$ is the number of items in the instrument; $\mathrm{S} 2 \mathrm{j}$ is the variance of each item; $\mathrm{S} 2 \mathrm{~T}$ is the total variance of all items.

Figure 8. Intensity of the dimensions of entrepreneurial mindset- professors

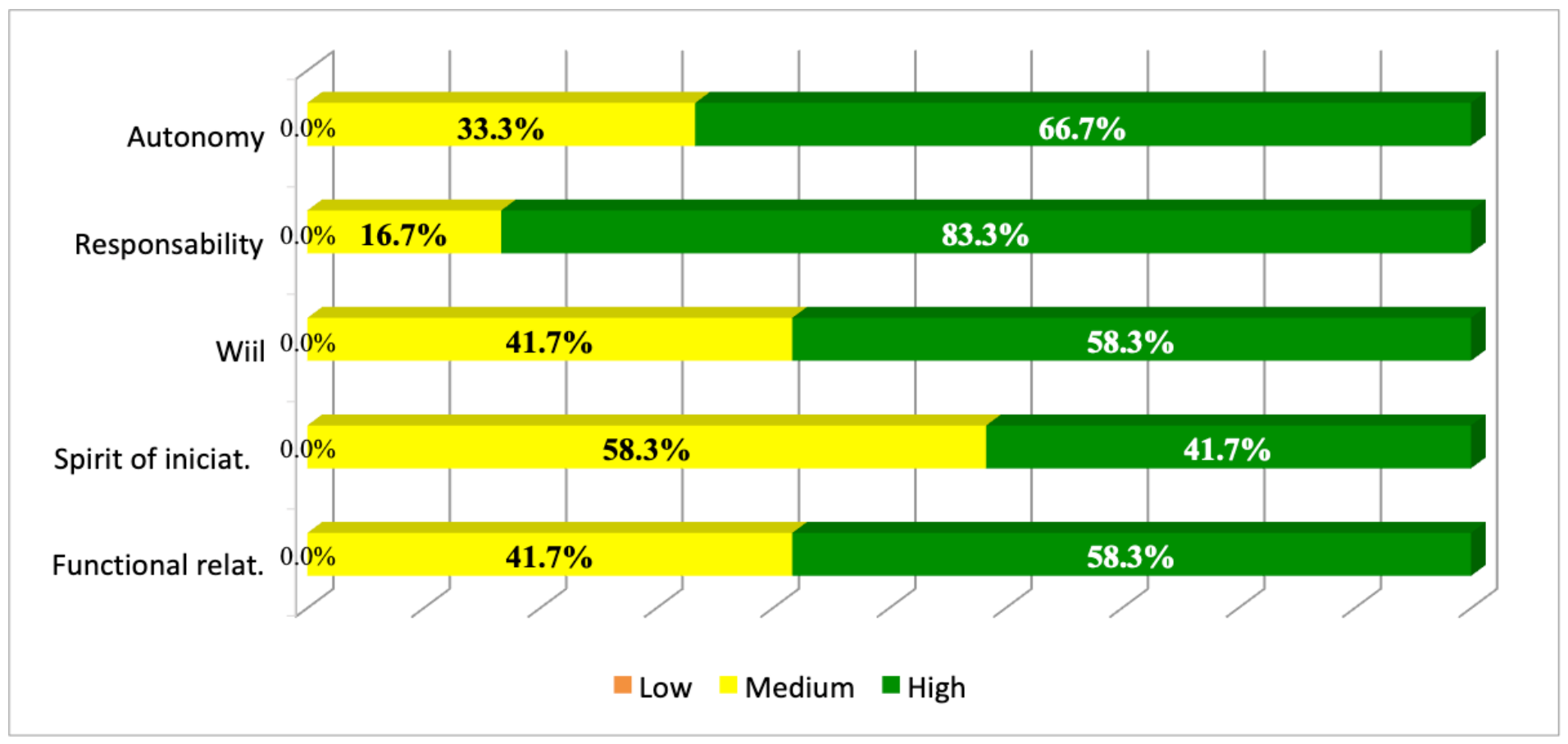

Fonte: elaborado pelos autores.

Revista de Negócios, v. 24, n. 2, p. 61-90, April, 2019. 
Cronbach's alpha for the EBCs instrument, which adopts Likert scale, obtained $\alpha=0.828$. Thus, the resulting values of the questionnaires with the 12 professors are reliable.

In order to establish the relation between the dimensions of entrepreneurial behavioral characteristics and dimensions of mindset, it was used Pearson's correlation coefficient, a parametric technique that indicates the measure of strength of association between two variables (Collis \& Hussey, 2005). For this study, we adopted the Lopes's conversion (2016), specified in Table 8.

Table 8. Interpretation of the values of correlation coefficient ${ }^{\circledR}$

\begin{tabular}{|c|c|}
\hline r value $(+$ or -$)$ & Interpretation* $^{*}$ \\
\hline 0.00 & Null \\
\hline 0.01 a 0.20 & Very weak \\
\hline 0.21 a 0.40 & Weak \\
\hline 0.41 a 0.60 & Moderate \\
\hline 0.61 a 0.80 & Strong \\
\hline 0.81 a 0.99 & Very strong \\
\hline 1.00 & Perfect \\
\hline
\end{tabular}

* Classification is only valid if the correlation value is significant, $\mathrm{p}<0.05$.

Source: Lopes (2016, p. 158).

According to Hair Jr. et al. (2005), Pearson's correlation coefficient has the objective of measuring the linear association between two metric variables and has a variation of -1.00 to 1.00. " $r$ " value coefficients near +1 indicate little dispersion and a strong positive correlation; when the values are close to "zero" it indicates much dispersion and an absence of relationship; and, finally, when the value of " $r$ " is close to -1 it indicates little dispersion and a strong negative correlation (Lopes, 2016).

The correlation matrix between the means of the entrepreneurial behavioral characteristics and the mindset dimensions of professors are presented in Table 9.

The correlation between the dimensions of entrepreneurial behavioral characteristics and the dimensions of the entrepreneurial mindset were mostly positive associations, very weak intensities (0.01 to 0.20$)$, weak $(0.21$ to 0.40$)$ and moderate ( 0.41 to 0.60$)$, indicating a direct relation between them. The strongest positive associations, of moderate intensity, are highlighted in gray in the table, and the strongest correlation was found between the EBC of commitment and the mindset dimension of autonomy (0.60). It was also the EBC commitment that had the highest number of moderate positive associations with the dimensions of mindset: autonomy (0.60), will (0.50), show initiative, spirit of initiative and problem solving (0.58) and functional relationships (0.41). Considering the dimensions of mindset, the one that presented the strongest

Table 9. Correlation of behavioral characteristics and entrepreneurial mindset - professors

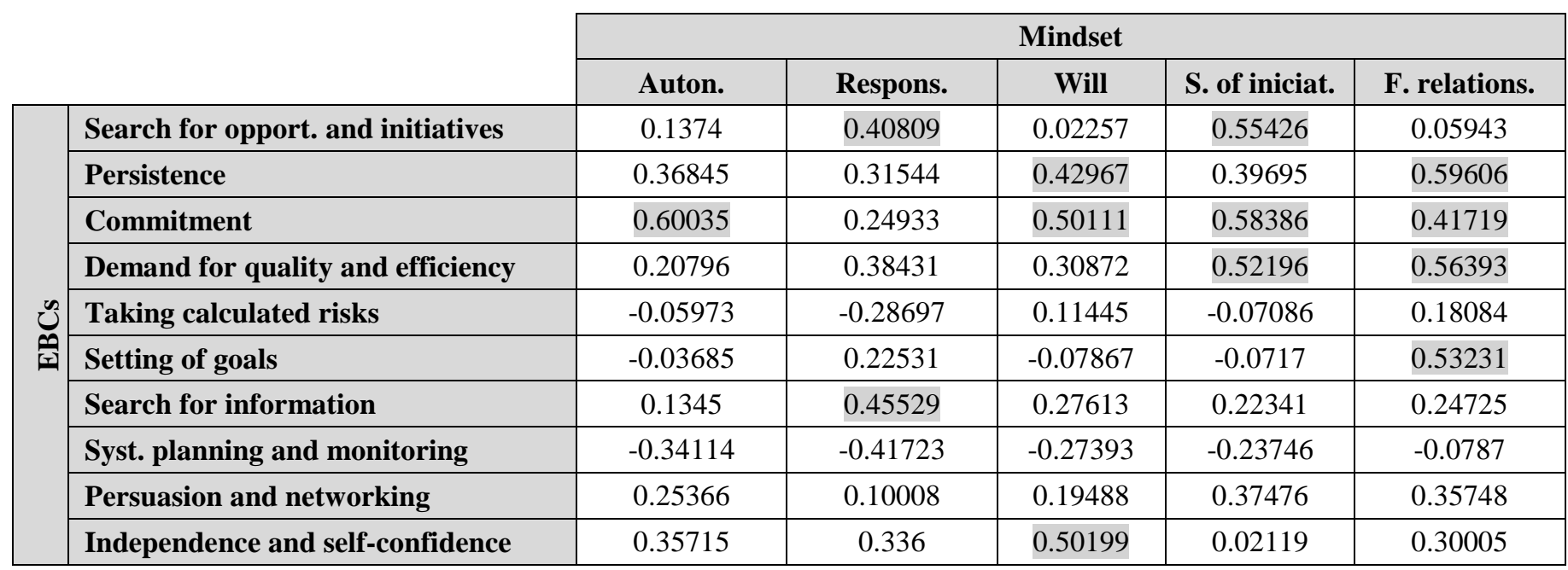

** Correlation is significant at the 0.01 level (bilateral).

Source: created by the authors.

Revista de Negócios, v. 24, n. 2, p. 61-90, April, 2019. 
correlations with EBCs was the ability to have functional relationships, with moderate positive associations with persistence (0.59), commitment (0.41), demand for quality (0.56) and setting of goals $(0.53)$.

The analysis of the results of the instruments applied to students will be shown next.

\subsection{Analysis of the students}

From the population of 427 students, 261 questionnaires were obtained in the three undergraduate courses of the college. 12 instruments were disregarded due to incomplete answers. The percentage of respondents for each course is presented in Table 1.

Table 1. Total respondents - students

\begin{tabular}{c|c|c|c}
\hline Course & $\begin{array}{c}\text { Total } \\
\text { students }\end{array}$ & Respondents & \% \\
\hline $\begin{array}{c}\text { Business } \\
\text { Administration }\end{array}$ & 137 & 94 & 68.6 \\
\hline $\begin{array}{c}\text { Information } \\
\text { Systems }\end{array}$ & 73 & 45 & 61.6 \\
\hline Law & 217 & 110 & 50.7 \\
\hline Totals & $\mathbf{4 2 7}$ & $\mathbf{2 4 9}$ & $\mathbf{5 8 . 3}$ \\
\hline
\end{tabular}

Source: created by the authors.

The sample was then comprised of 249 undergraduate students, a number greater than the calculated minimum sample, representing 58.3\% of the population. The profile of the respondents is presented in Table 10.

Table 10. Characteristics of the sample - students

\begin{tabular}{|c|c|c|c|}
\hline \multirow[t]{2}{*}{ Category } & \multirow[t]{2}{*}{ Variables } & \multicolumn{2}{|c|}{ Frequency } \\
\hline & & Absolute & $\%$ \\
\hline \multirow[t]{2}{*}{ Sex } & Male & 131 & 52.82 \\
\hline & Female & 117 & 47.18 \\
\hline \multirow[t]{3}{*}{ Marital status } & Married (a) & 17 & 6.94 \\
\hline & Single (a) & 219 & 89.39 \\
\hline & $\begin{array}{l}\text { Separated } \\
\text { (a) }\end{array}$ & 9 & 3.67 \\
\hline \multirow[t]{5}{*}{ College year } & 1 year & 79 & 31.73 \\
\hline & 2nd year & 44 & 17.67 \\
\hline & 3rd year & 51 & 20.48 \\
\hline & 4th year & 60 & 24.10 \\
\hline & 5 th year & 15 & 6.02 \\
\hline \multirow[t]{2}{*}{ Works } & Yes & 212 & 85.48 \\
\hline & No & 36 & 14.52 \\
\hline \multirow{2}{*}{$\begin{array}{l}\text { Had } \\
\text { entrepreneurial } \\
\text { training at under }\end{array}$} & Yes & 245 & 98.39 \\
\hline & No & 4 & 1.61 \\
\hline
\end{tabular}

\begin{tabular}{|l|c|c|c|}
\cline { 2 - 4 } graduation & & & \\
\hline $\begin{array}{l}\text { Has or had } \\
\text { entrepreneurial } \\
\text { activity in the } \\
\text { family }\end{array}$ & Yes & 54 & 22.04 \\
\cline { 2 - 4 } Category & No & & \\
\hline Age & Parameters & \multicolumn{2}{|c|}{ Values } \\
\cline { 2 - 3 } & Min. & \multicolumn{2}{|c|}{17} \\
\cline { 2 - 3 } & Max. & \multicolumn{2}{|c|}{68} \\
\hline
\end{tabular}

Source: created by the authors.

The analysis began with the calculation of minimum, maximum, mean values and standard deviation for each dimension of behavioral characteristics and entrepreneurial mindset. Table 11 shows the descriptive statistics of the instruments used in this study.

Table 11. Descriptive statistics - students

\begin{tabular}{|c|c|c|c|c|c|}
\hline & $\begin{array}{c}\text { Dimension/ } \\
\text { Characteristic }\end{array}$ & Min & $\operatorname{Max}$ & $\begin{array}{l}\text { Mean } \\
\text { value }\end{array}$ & SD \\
\hline \multirow{10}{*}{$\bigcup_{\substack{0 \\
\text { I }}}^{n}$} & $\begin{array}{l}\text { Search for } \\
\text { opportunities and } \\
\text { iniciative }\end{array}$ & 13 & 25 & 19.277 & 1.987 \\
\hline & Persistence & 10 & 23 & 17.594 & 2.008 \\
\hline & Commitment & 12 & 25 & 20.401 & 2.360 \\
\hline & $\begin{array}{l}\text { Demand for } \\
\text { quality and } \\
\text { efficiency }\end{array}$ & 8 & 25 & 19.008 & 2.918 \\
\hline & $\begin{array}{l}\text { Taking calculated } \\
\text { risks }\end{array}$ & 9 & 23 & 16.927 & 2.378 \\
\hline & $\begin{array}{l}\text { Setting of } \\
\text { goals }\end{array}$ & 13 & 25 & 20.634 & 2.441 \\
\hline & $\begin{array}{l}\text { Search for } \\
\text { information }\end{array}$ & 10 & 25 & 19.514 & 2.732 \\
\hline & $\begin{array}{l}\text { Systematic } \\
\text { planning and } \\
\text { monitoring }\end{array}$ & 10 & 25 & 18.060 & 2.459 \\
\hline & $\begin{array}{l}\text { Persuasion and } \\
\text { Networking }\end{array}$ & 10 & 25 & 17.911 & 2.467 \\
\hline & $\begin{array}{l}\text { Independence and } \\
\text { self-confidence }\end{array}$ & 12 & 25 & 19.473 & 2.255 \\
\hline \multirow{5}{*}{ 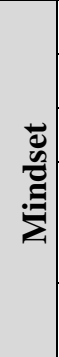 } & Autonomy & 2 & 13 & 8.815 & 2.470 \\
\hline & Responsibility & 2 & 16 & 10.967 & 2.993 \\
\hline & Will & 1 & 12 & 8.228 & 2.467 \\
\hline & $\begin{array}{l}\text { Spirit of } \\
\text { initiative and } \\
\text { problem solving }\end{array}$ & 0 & 12 & 7.803 & 2.344 \\
\hline & $\begin{array}{l}\text { Functional } \\
\text { Relations }\end{array}$ & 0 & 8 & 5.204 & 1.661 \\
\hline
\end{tabular}

Source: created by the authors

From these data, it is possible to identify the minimum and maximum scores for each dimension of entrepreneurial behavioral characteristics and mindset, as well as the mean

Revista de Negócios, v. 24, n. 2, p. 61-90, April, 2019. 
values and standard deviation. Regarding the entrepreneurial behavioral characteristics, the maximum limit is 25 points, reached in 8 out of 10 behavioral characteristics by students, and the minimum limit of 5 points was not verified in any characteristic. A minimum score below 15 points, indicating the lack of the characteristic, was seen in all dimensions, indicating that one or more students do not have that behavioral trait.

In the case of mindset, each dimension has its own maximum limit, which varies according to the number of questions for each dimension. In four dimensions, one or more students reached the maximum limit: autonomy (13 points), responsibility (16 points), will (12 points), and functional relationships with the group (8 points). The minimum limit of this instrument is the absence of punctuation, not seen in two dimensions: spirit of initiative and problem solving, and functional relationships. The smallest standard deviation was found in the dimension demand for quality and efficiency, from the entrepreneurial behavioral characteristics, and the dimension responsibility, from the mindset.

All 10 of the students' EBCs were with mean values above 15 points, indicating the existence of entrepreneurial behavioral characteristics (Mansfield et al., 1987), as shown in Figure 9.
Figure 9. Distribution of means of entrepreneurial behavioral characteristics - students

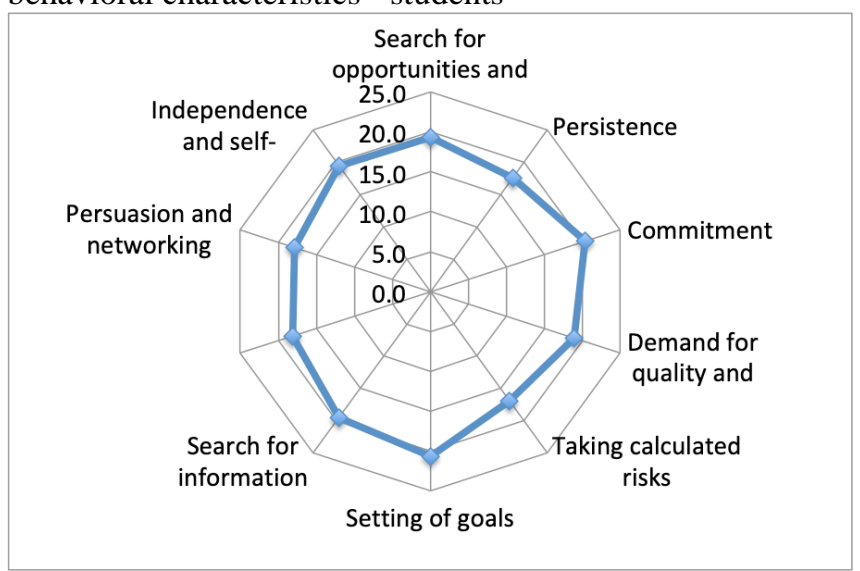

Source: created by the authors.

In relation to the mean values, among the 10 entrepreneurial behavioral characteristics, the setting of goals stands out, presenting the greatest average of 20.6 points. As for the lowest average, it was obtained for the characteristic taking calculated risks, with 16.9 points.

In Figure 10, it is possible to see the mean values of each dimension of the EBCs for students, using the stratification for intensities adopted for this research.

As it may be seen in Figure 10, six behavioral characteristics exhibited means with medium intensity (search for opportunities and

Figure 10. Mean values of entrepreneurial behavioral characteristics - students

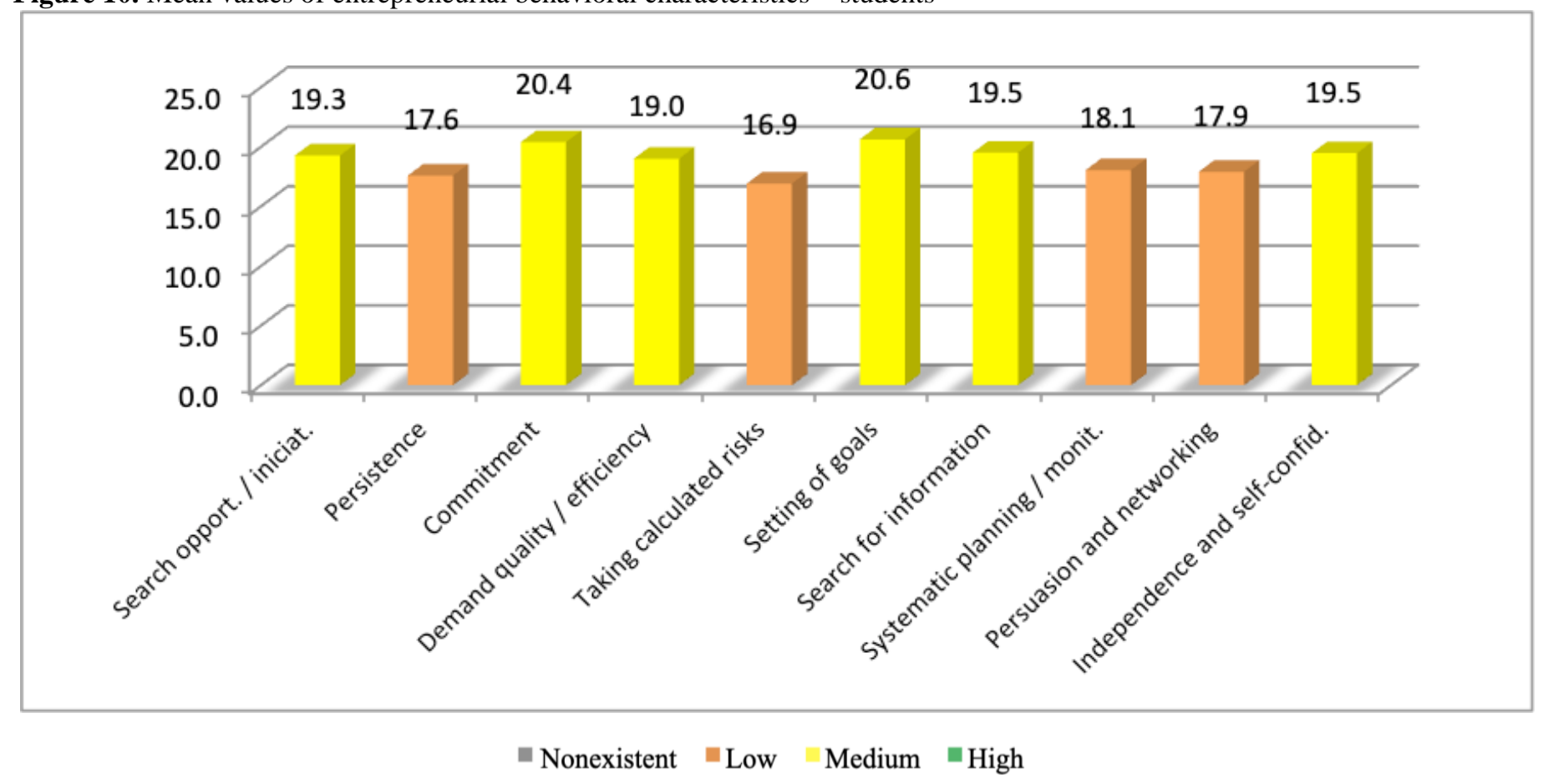

Source: created by the authors.

Revista de Negócios, v. 24, n. 2, p. 61-90, April, 2019. 
initiative, commitment, setting of goals, demand for quality and efficiency, search for information, and independence and self-confidence) and four characteristics presented averages with low intensity (persistence, taking calculated risks, systematic planning and monitoring and persuasion and networking).

To better understand these data, it was calculated the percentages of the intensities of each characteristic (Figure 11). To do this it is used the color stratification adopted with the professors: gray corresponds to absent characteristic (up to a maximum of 15 points), orange represents that the characteristic is low (15.0 to 18.3), yellow considered medium ( 18.3 to 21.7) and in green the characteristic is considered high (18.3 to 25$)$.

The characteristic with the highest mean value, setting of goals (20.6 points), is also the one that has the best distribution of intensities: the highest percentage of students with high intensity $(39.8 \%)$ and the lowest percentage with nonexistent characteristic $(1.2 \%)$. This feature is related to the individual who sets long-term goals, clear and specific, continually defining and reviewing the short-term goals (MSI, 1990). This is an important behavior when undertaking a business or project, and we can infer that this characteristic has higher intensity in the students investigated because of the kind of learning, based on problems and challenges, and because of the projects that they develop along the subjects and entrepreneurial education projects present in the investigated institution of higher education.

As for the behavioral characteristic with the worst distribution of intensities, it is taking calculated risks, with the highest percentage of students with non-existent characteristic $(12.45 \%)$ and the lowest percentage of students with high intensity (1.6\%). As mentioned in the analysis of

Figure 11. Intensity of entrepreneurial behavioral characteristics - students

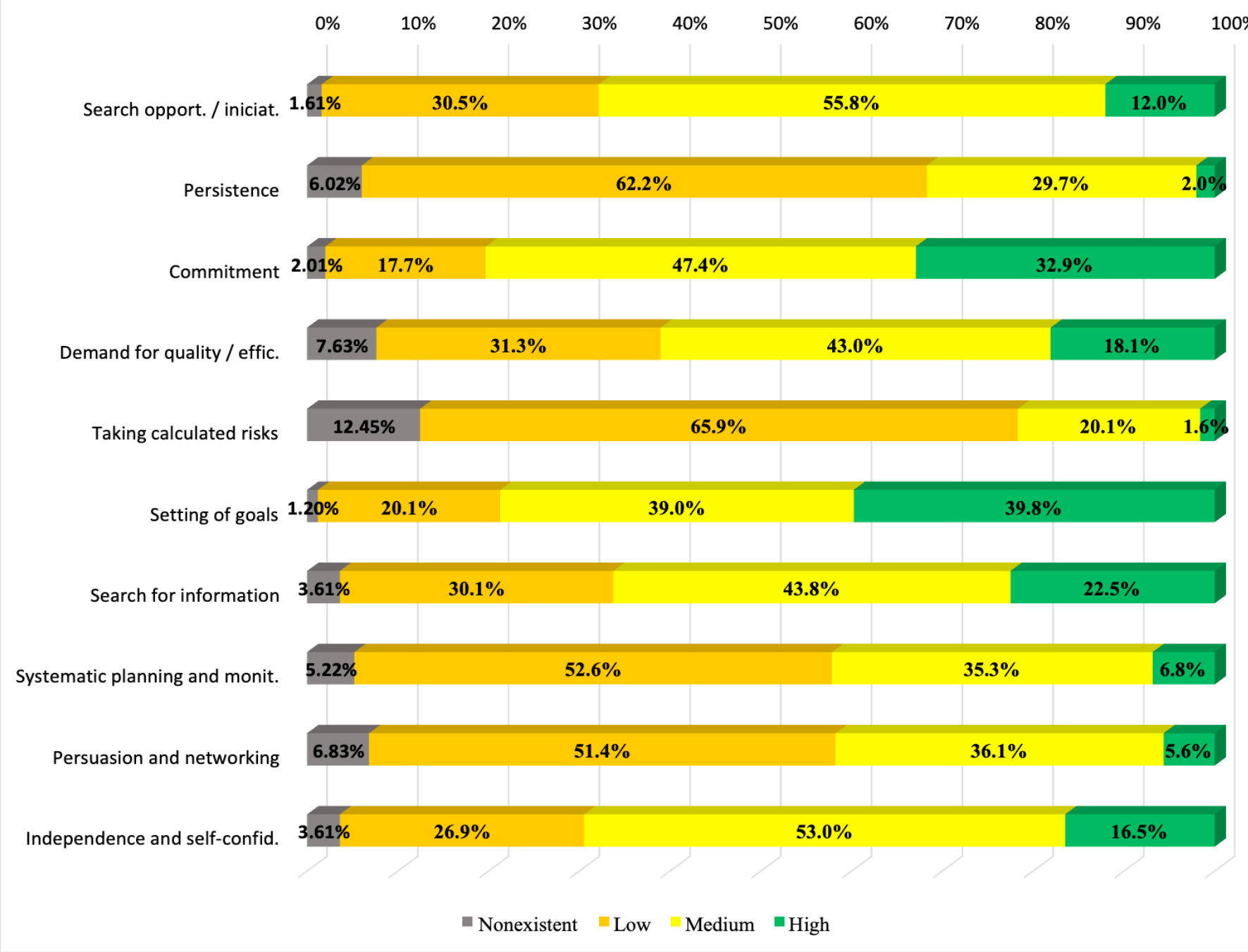

Source: created by the authors.

Revista de Negócios, v. 24, n. 2, p. 61-90, April, 2019. 
quantitative data of professors, in which this characteristic also showed a lower intensity, taking calculated risks refers to the attitude of evaluating and calculating the risks deliberately, taking steps to reduce them or control the results (MSI, 1990). This feature can be developed, both in professors and in students, encouraging them to place themselves in situations involving challenges or moderate risks inherent to the entrepreneurial activity.

To estimate the reliability, the internal consistency was measured by Cronbach's alpha (Sampieri, Collado \& Lucio, 2013; Lopes, 2016). Cronbach's alpha for the instrument of EBCs, using the Likert scale, obtained $\alpha=0.831$. This way, the resulting values of the questionnaires with 249 undergraduate students are reliable.

Next, in Figure 12, the mean values of the mindset dimensions of the students are shown, with the points obtained for each dimension and missing points to the total, considering that this varies for each dimension (Mencarelli, 2014).

Figure 12. Mean values for mindset dimensions - students

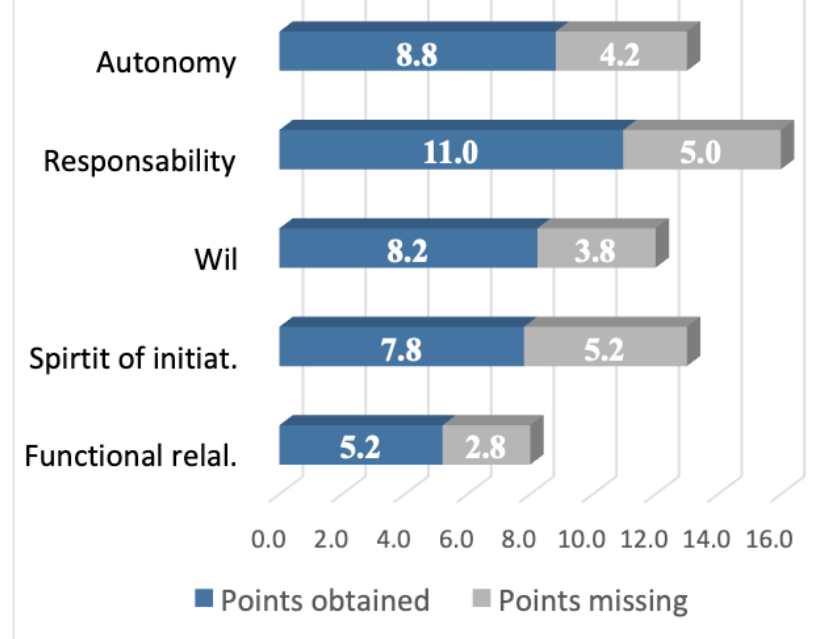

Source: created by the authors.

It may be seen in the figure that the highest proportional averages between the dimensions of mindset of the students are responsibility and will, and the lowest proportional average is the spirit of initiative and problem solving.

Figure 13 shows the mean value of each dimension of the entrepreneurial mindset of students, considering the instrument reading key presented in the methodological procedures and the stratification by color adopted in this research.
Figure 13. Intensity of mean value of the dimensions of entrepreneurial mindset - students

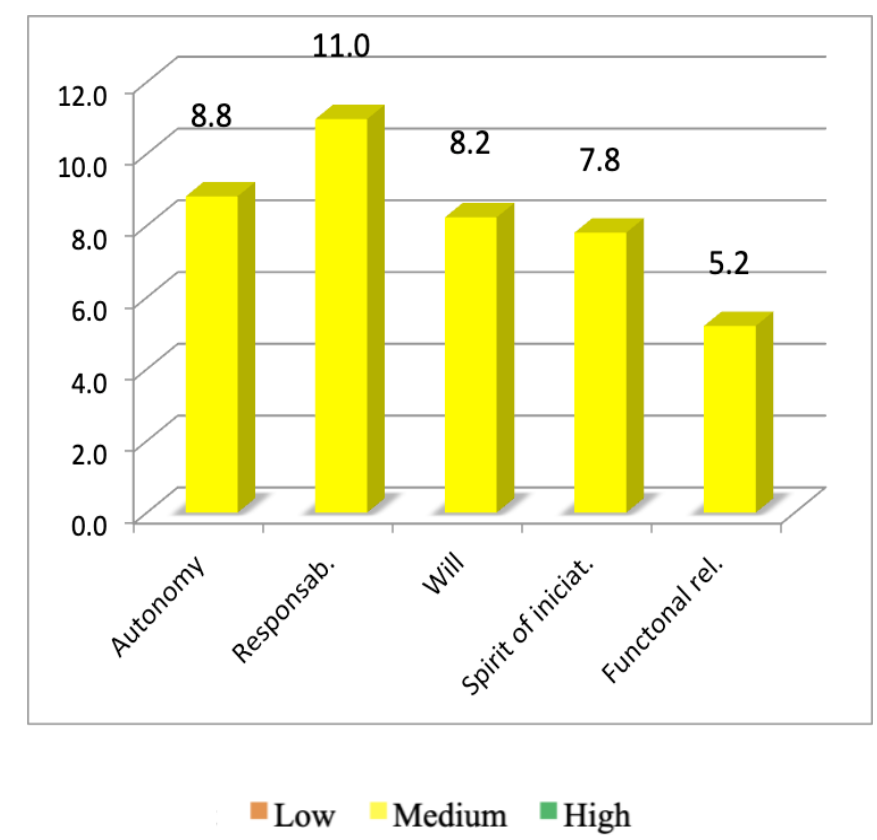

Source: created by the authors.

It can be seen that all five dimensions of mindset presented mean values with medium intensity: autonomy (8.8 points out of 13), responsibility (11 points out of 16), will (8.2 points out of 12), spirit of initiative and problem solving (7.8 points out of 13) and functional relationships (5.2 points out of 8).

To better understand this data, it was calculated the percentages of the intensities of the entrepreneurial mindset dimensions of students, reported in Figure 14. It is inferred, from the figure, that the 249 students investigated showed predominance of medium intensities for mindset dimensions, followed by high intensities, with the exception of the dimension ability to manage functional relationships, which presented the highest percentage of high intensities (48.2\%), with an average in the boundary between medium and high intensity. This dimension refers to the individual with entrepreneurial mindset able to manage relationships in a functional manner, that is, with advantage and reference to his scope. $\mathrm{He}$ is able to resolve a situation without controversy or resort to assistentialism, but managing relations intelligently and creating harmony among the people who are functional to that scope (Mencarelli, 2014). 
The students also showed a small percentage of low intensities in all dimensions, which was higher in the dimension spirit of initiative and problem solving (16.9\%). As described in the analysis of professors, who also had the lowest percentage in this dimension, having spirit of initiative and problem solving is related to the characteristic of being creative in situations, placing yourself before the problem in a purposeful and decisive manner (Mencarelli , 2014). Having knowledge of this lower performance and adopting pedagogical strategies aimed at its development, it can be enhanced in the students this dimension of entrepreneurial mindset related to the orientation to results and solving problems, mainly because one of the particularities of entrepreneurial education is precisely being based on problem solving learning (Lopes, 2010; Mendes, 2011).

In the sequence, the correlation matrix was made among the mean values of entrepreneurial behavioral characteristics and mindset of students, which is presented in Table 12.

It is found that the correlation between entrepreneurial behavioral characteristics and dimensions of entrepreneurial mindset were

Figure 14. Percentages of the intensities of dimensions of entrepreneurial mindset - students

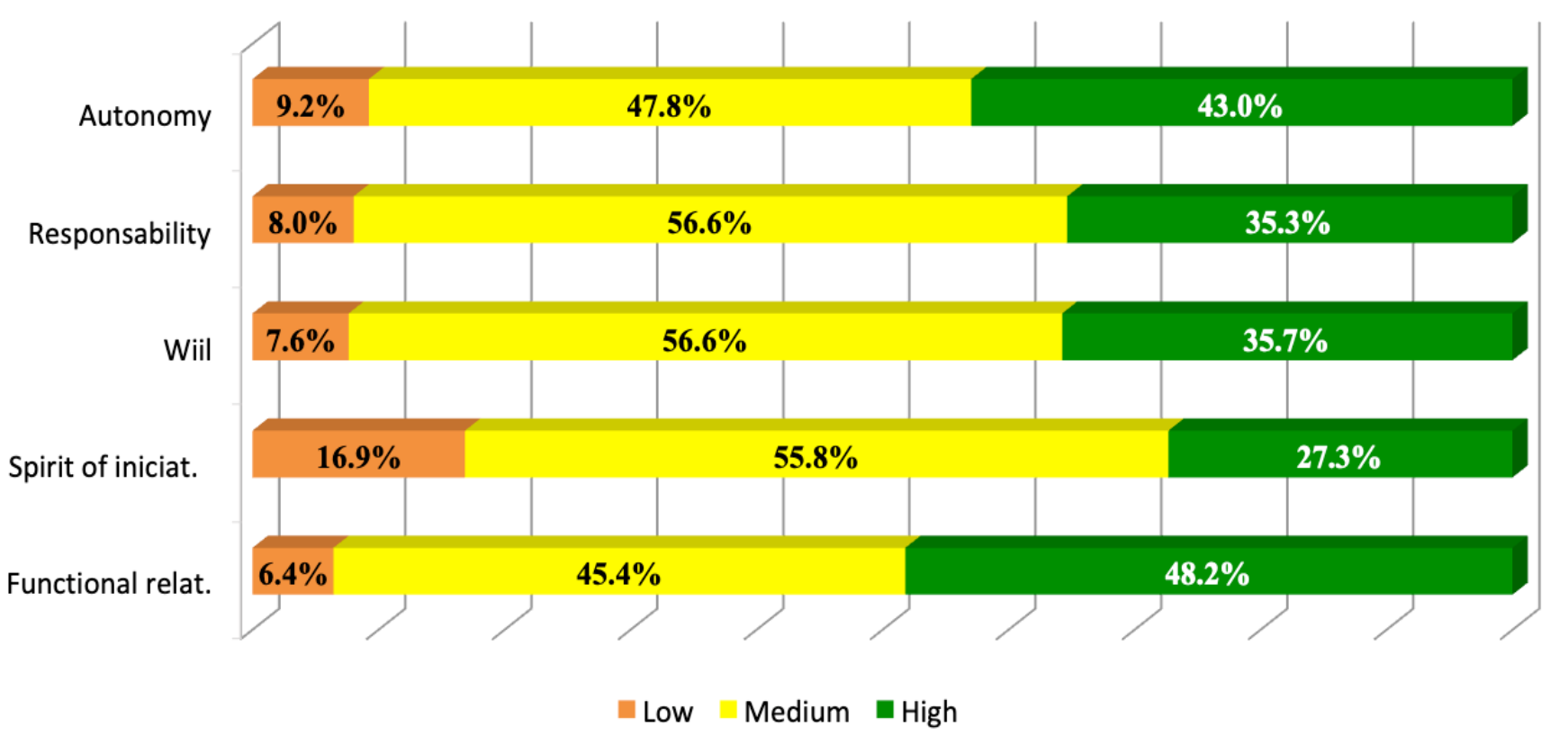

Fonte: elaborado pelos autores

Table 12. Correlation of entrepreneurial behavioral characteristics and mindset - students

\begin{tabular}{|c|c|c|c|c|c|c|}
\hline & \multicolumn{5}{|c|}{ Mindset } \\
\hline & & Auton. & Auton. & Auton. & Auton. & Auton. \\
\hline \multirow{10}{*}{ 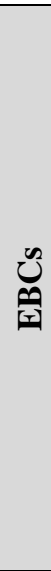 } & $\begin{array}{l}\text { Search for opportunities and } \\
\text { initiative }\end{array}$ & 0.20508 & 0.18449 & 0.21392 & 0.17873 & 0.23549 \\
\hline & Persistence & -0.13547 & -0.11153 & -0.07477 & -0.04357 & 0.07335 \\
\hline & Commitment & 0.22921 & 0.2735 & 0.36699 & 0.32689 & 0.20514 \\
\hline & Demand for quality and efficiency & -0.07306 & 0.04112 & 0.04286 & 0.00389 & -0.0702 \\
\hline & Taking calculated risks & -0.05925 & 0.0042 & -0.03427 & -0.04667 & 0.03642 \\
\hline & Setting of goals & -0.00857 & 0.14464 & 0.1157 & 0.01909 & 0.12989 \\
\hline & Search for information & 0.00039 & 0.07696 & 0.07217 & 0.0448 & 0.15433 \\
\hline & Systematic planning and monitoring & 0.05493 & 0.10434 & 0.11267 & 0.11464 & 0.10157 \\
\hline & Persuasion and networking & -0.06024 & -0.02878 & 0.00135 & 0.04507 & 0.13131 \\
\hline & Independence and self-confidence & 0.10766 & 0.07333 & 0.12241 & 0.15874 & 0.15259 \\
\hline
\end{tabular}

** Correlation is significant at the 0.01 level (bilateral).

Source: created by the authors.

Revista de Negócios, v. 24, n. 2, p. 61-90, April, 2019. 
mostly positive associations very weak and weak intensity, indicating a direct relation between them. The entrepreneurial behavioral characteristic with the strongest correlations with the mindset dimensions was commitment, which had the highest intensities in the correlation with the dimension will (0.36) and spirit of initiative (0.32).

After analyzing the results of the applied instruments separately, it is made an analysis of all data, crossing the entrepreneurial behavioral characteristics and mindset of professors and students in order to identify possible similarities and discrepancies.

4.3 Comparative analysis of professors and students

The relationships of the data collected are analyzed as follows, crossing the mean values and intensities of entrepreneurial behavioral characteristics and mindset of professors with the means and intensities of students.

Initially, it is compared the distribution of the means of entrepreneurial behavioral characteristics between professors and students, as illustrated in Figure 15.
Figure 15. Distribution of means of entrepreneurial behavioral characteristics - professors and students

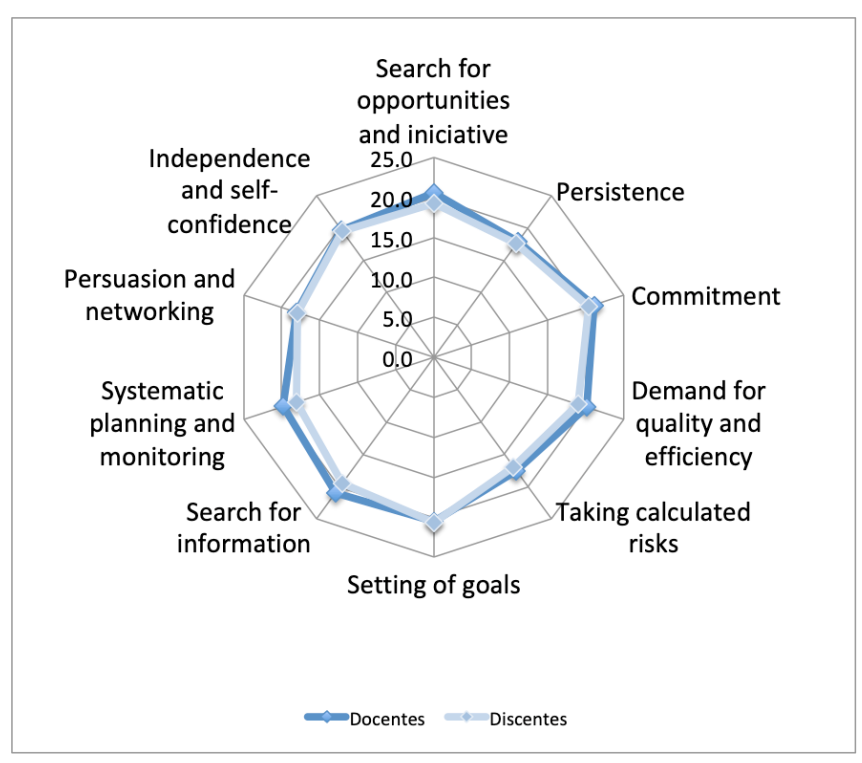

Source: created by the authors.

Considering the minimum score of 15 points, the investigated professors and students in this study may be considered entrepreneurs (Mansfield et al., 1987). What can also be seen in the graph lines is that there is a direct correlation between the averages of the behavioral characteristics of the two groups.

In order to better understand this

Figure 16. Mean value of entrepreneurial behavioral characteristics - professors and students

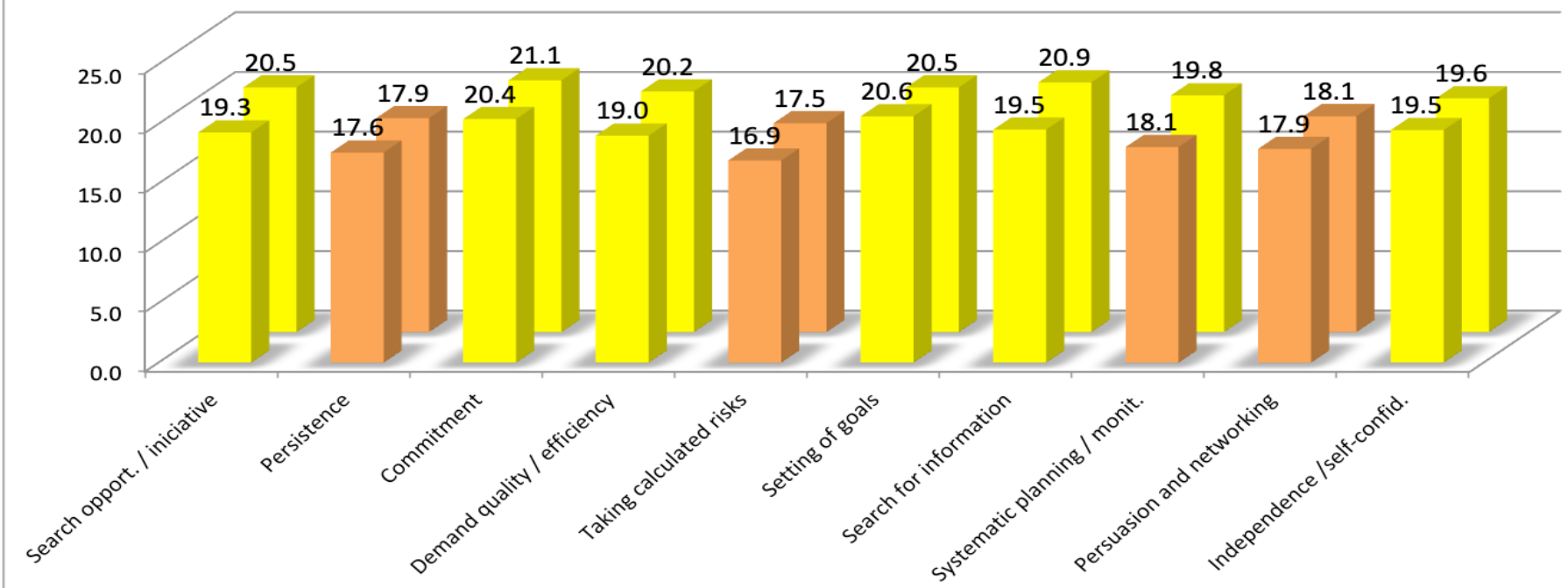

Nonexistent $=$ Low Medium $\quad$ High

Source: created by the authors.

Revista de Negócios, v. 24, n. 2, p. 61-90, April, 2019. 
relationship, Figure 16 compares the mean value of the entrepreneurial behavior characteristics of professors and students, from the colors of the stratification scale created for this research.

From the data presented in Figure 16, it is possible to identify a relationship between the mean values and intensities of entrepreneurial behavioral characteristics of analyzed professors and students. Professors have averages a little higher than the students, except for the characteristic setting of goals, with the average of students (20.6 points) being slightly higher than that of professors (20.5 points). In the other characteristics, the mean value of professors is higher, with the greatest difference in the characteristic systematic planning and monitoring (1.7 points). In relation to the intensity of the means, all the characteristics have the same intensity for professors and students, with the exception of the characteristic systematic planning and monitoring, in which the students have low intensity (18.1), and professors show high intensity (19.8), with the largest difference between the groups, as previously explained. This feature refers to the individual who plans, dividing large tasks into sub-tasks with deadlines, and constantly reviews his plans (MSI, 1990). Being aware of the difference in this feature, more developed in the professors than in the students, professors can create teaching strategies in entrepreneurial education projects that they already have in order to intensify this aspect also in their students.

To analyze in a more detailed way the relationship between EBCs, Figure 17 brings the calculation of percentages of the intensities of each behavioral characteristic in both professors and students.

From the percentage of responders for each entrepreneurial behavioral characteristic,

Figure 17. Intensity of entrepreneurial behavioral characteristics - professors and students

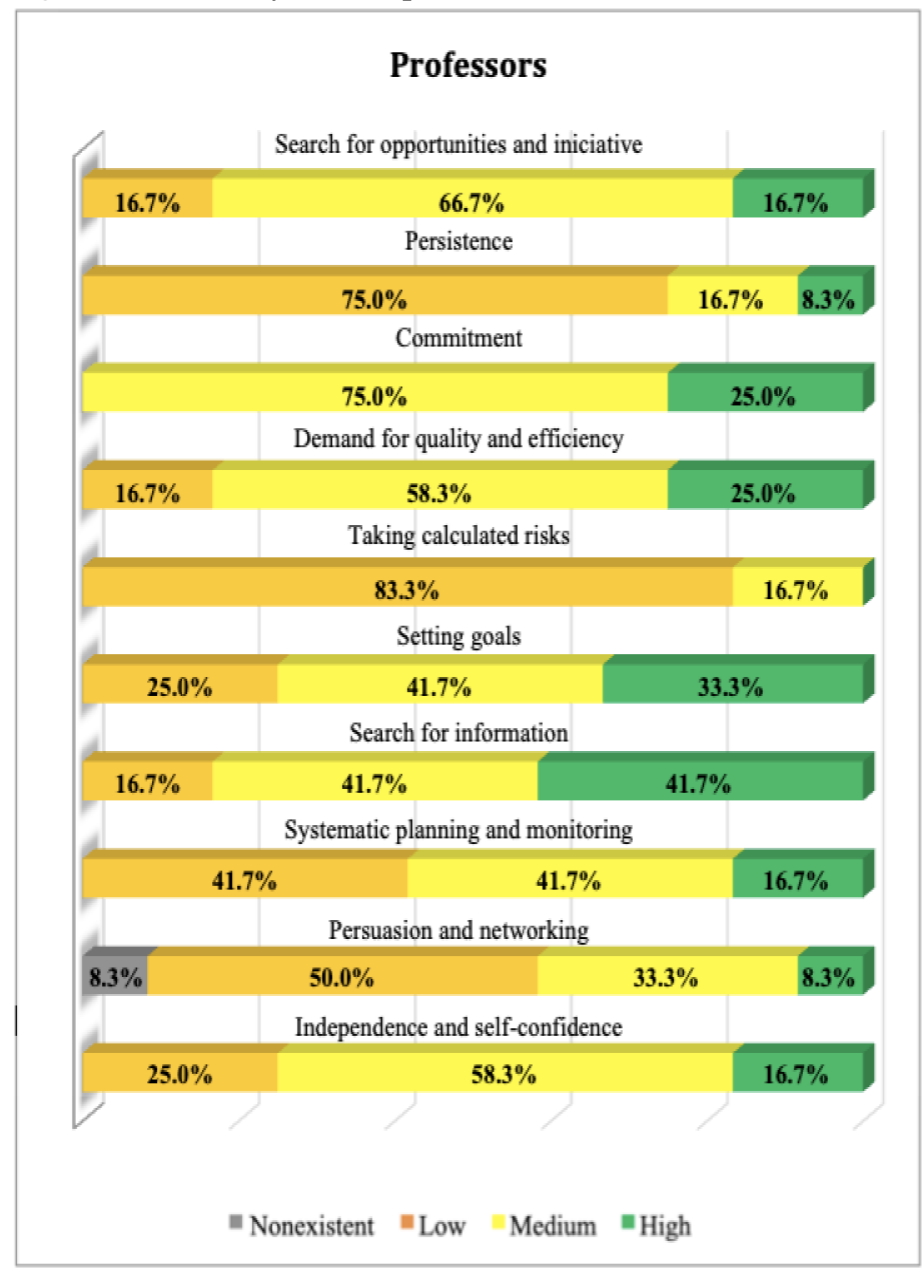

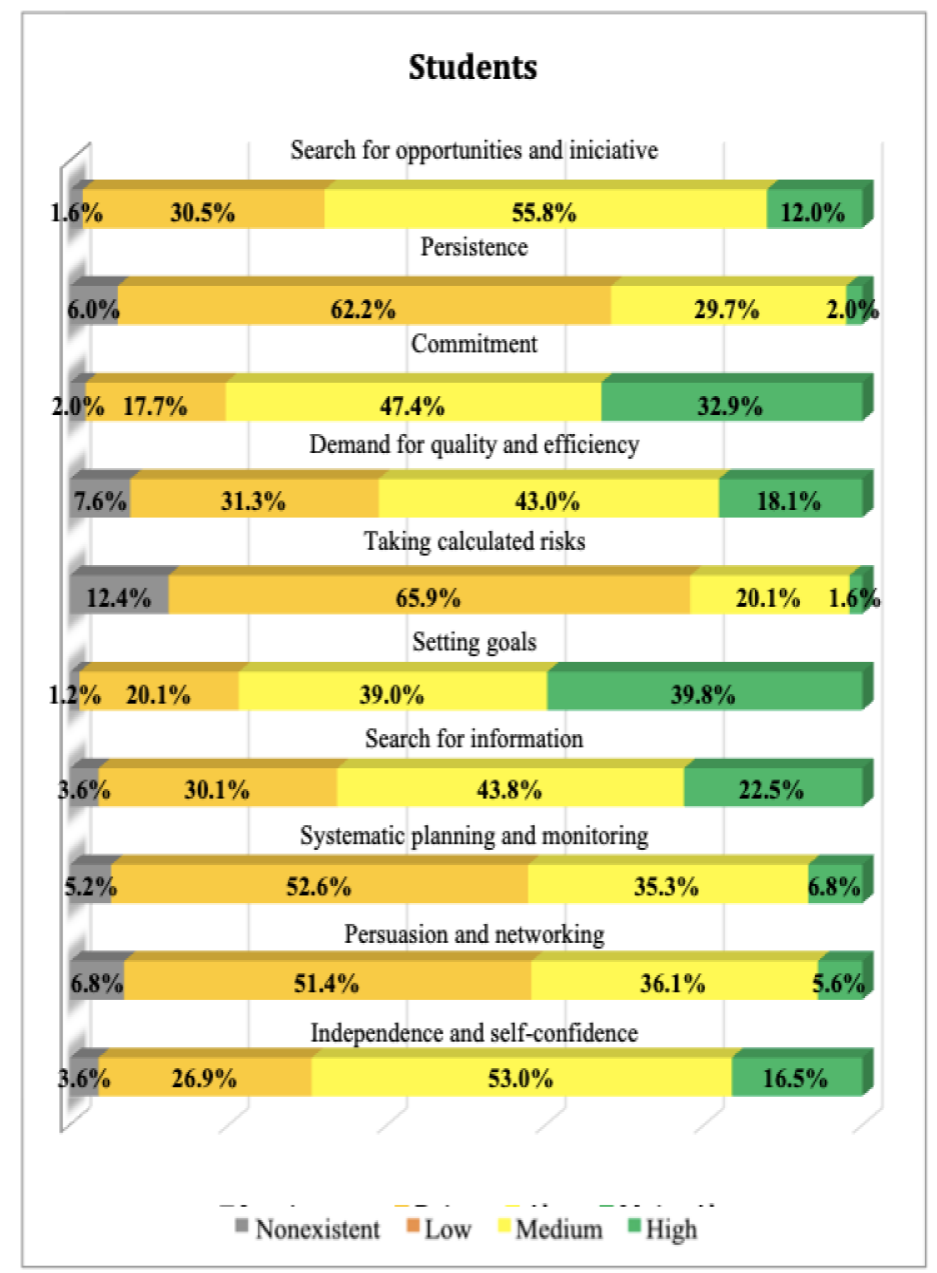

Source: created by the authors.

Revista de Negócios, v. 24, n. 2, p. 61-90, April, 2019. 
compared among professors and students in Figure 17, it may be seen that professors have percentages of respondents with high intensities slightly greater than the students in most characteristics. Among the students, there is still a small percentage of respondents who show nonexistent behavioral characteristics, which appears for professors only in the persuasion and networking characteristic.

Although there is this difference - expected given that professors have stronger entrepreneurial characteristics than the students, because of the activity they carry out, and also considering their professional experience and greater life experience (Krüger \& Minello, 2017) - comparing the intensities between the two graphs can identify a correlation between the two graphs, a correlation between the percentages of EBCs in professors and students in most characteristics.

Turning to the entrepreneurial mindset in both groups, Figure 18 shows the means of the dimensions of professors and students, as measured by the Forma mentis test (Mencarelli, 2014), with points obtained for each dimension and missing points to the maximum limit.

It can be observed in Figure 18 that, as in the graphs relating to the entrepreneurial behavioral characteristics, there is also a certain relationship in the results of entrepreneurial mindset in the professors and students investigated in this research.

To better understand this relationship, Figure 19 shows the average of each dimension of the entrepreneurial mindset of professors (left

Figure 18. Mean value of the dimensions of entrepreneurial mindset - professors and students

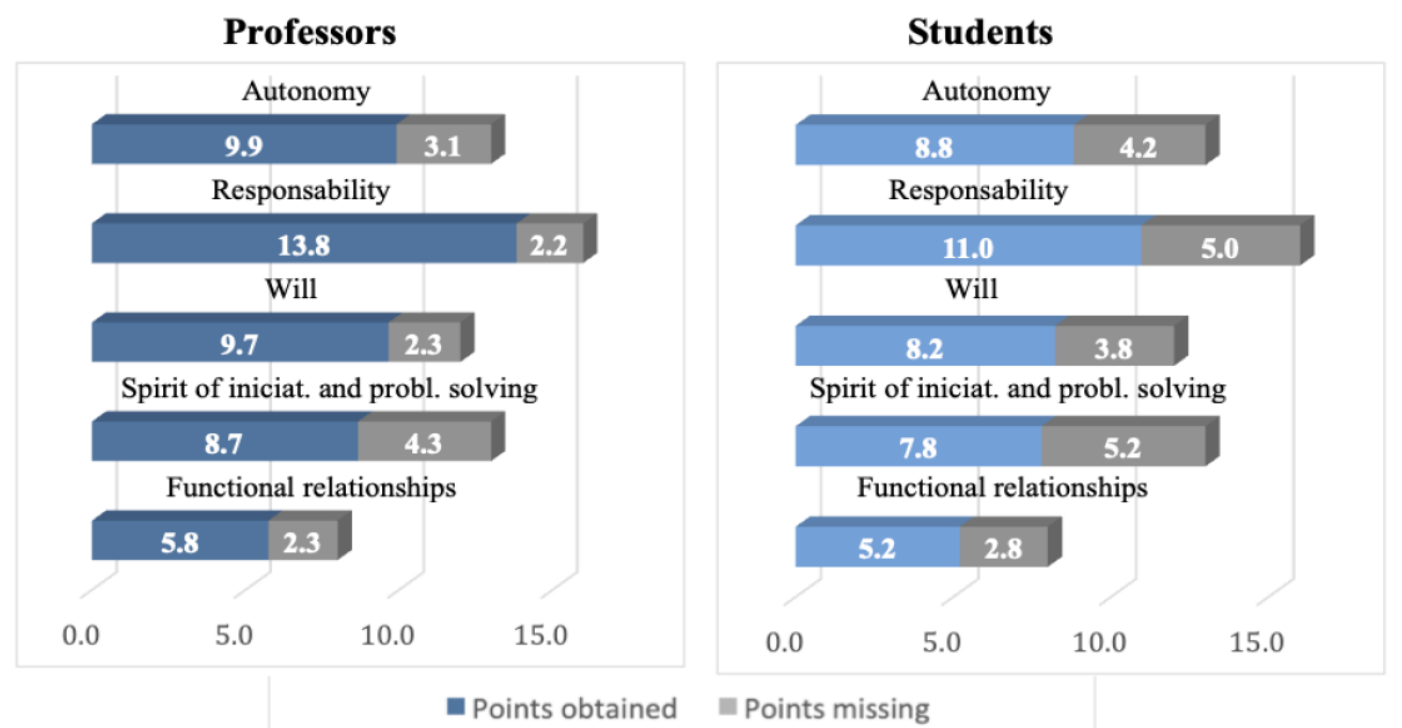

Source: created by the authors.

Figure 19. Intensity of the means of dimensions of entrepreneurial mindset - professors and students

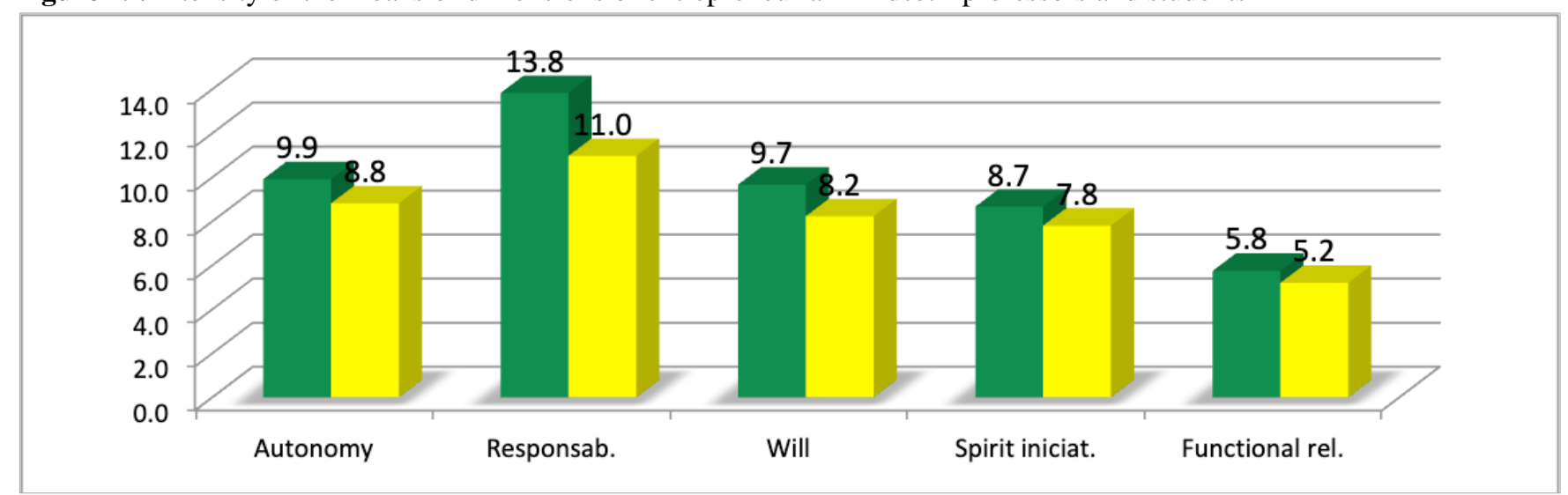

Source: created by the authors.

Revista de Negócios, v. 24, n. 2, p. 61-90, April, 2019. 
columns) and students (right columns) with stratification by colors identifying the intensity of each dimension.

As it can be read in Figure 19, the dimension with the greatest difference is responsibility, with high intensity for professors (13.8 points) and medium intensity for students (11.0 points). As for the dimension of entrepreneurial mindset with the closest values is the spirit of initiative and problem solving, with medium intensity both for professors ( 8.7 points) and students ( 7.8 points).

To further understand these relationships, Figure 20 shows the calculation of percentages of intensities in each dimension of entrepreneurial mindset in both groups.

From the figure, it can be confirmed that the greatest difference between the dimensions of entrepreneurial mindset is responsibility, which has a high intensity in $83.3 \%$ of the professors and in $35.3 \%$ of the students.
To Mencarelli (2014), responsibility concerns the mindset of the individual entrepreneur, asking himself about the first causes of what happens, trying to harvest his potential responsibilities. It features a mature individual with a sense of constructive self-criticism, that does not blame something external for causes or the events surrounding him. Being aware of these results, professors can intensify activities and adopt didactic and pedagogical strategies in order to increase this dimension in their students.

In relation to the other four dimensions, one can notice a more direct relationship between the results. Excluding the dimension of responsibility, it may be graphically noticed a ratio of intensities between professors and students in the other dimensions, with percentages of high intensity slightly higher in professors and presence of some respondents with low intensities among students. As already identified by Krüger and Minello (2017), professors have stronger entrepreneurial

Figure 20. Percentages of the intensities of the dimensions of entrepreneurial mindset - professors and students

\section{Professors}

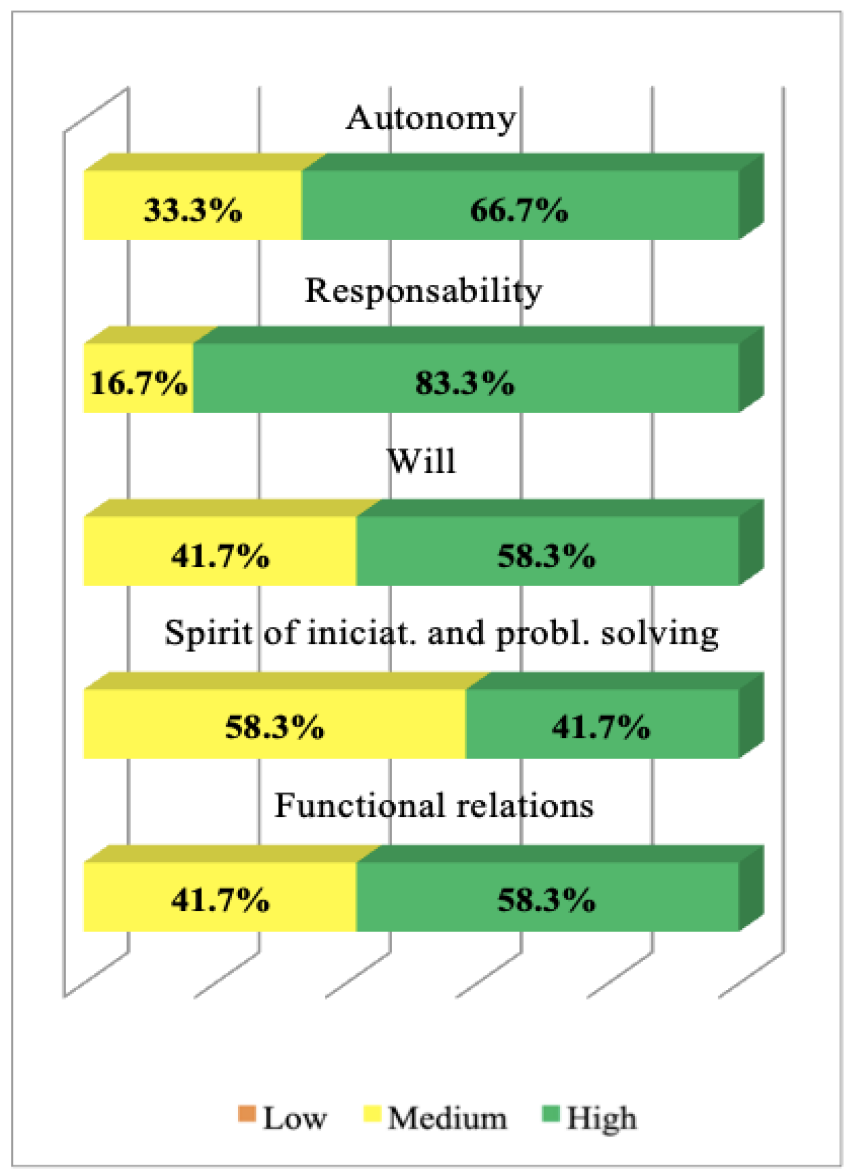

Students

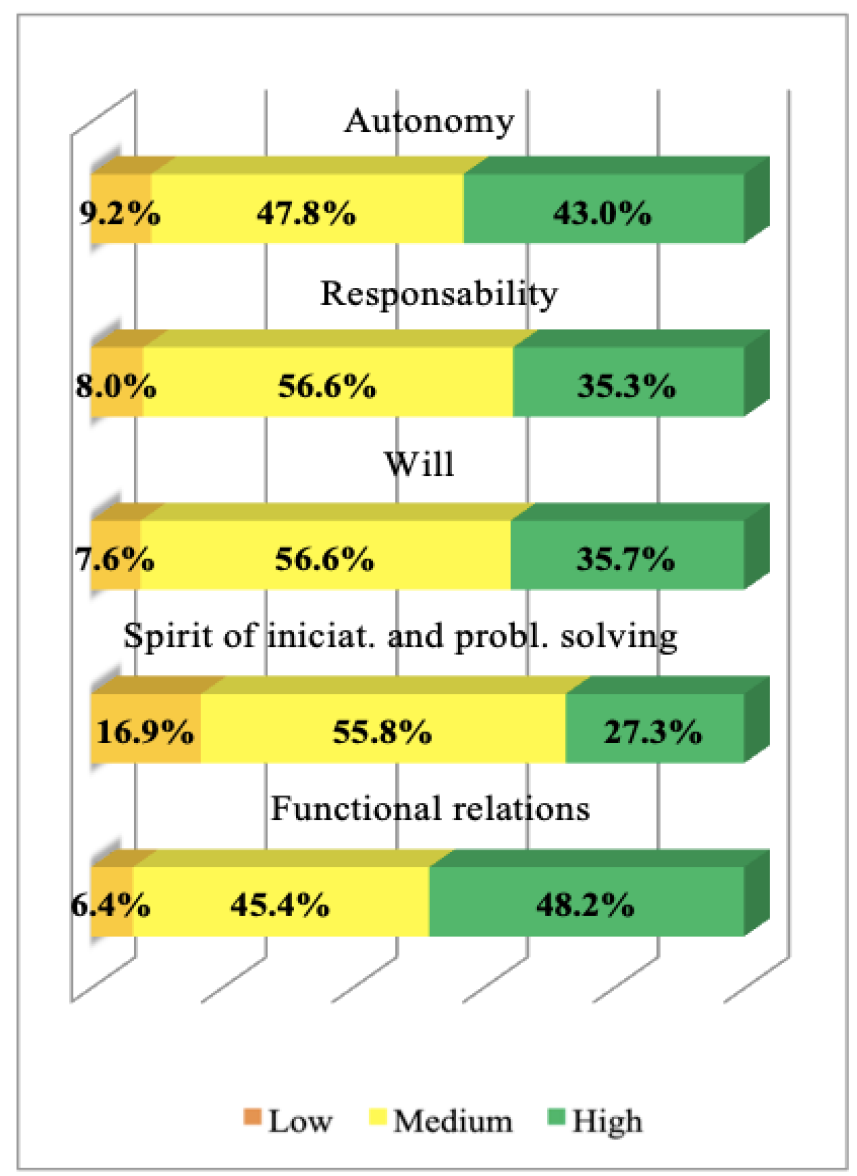

Source: created by the authors.

Revista de Negócios, v. 24, n. 2, p. 61-90, April, 2019. 
characteristics than the students, due to the course of study already taken, professional activities that they carry out and their greater life experience.

Seeking to advance in the understanding of the correlation between the results of entrepreneurial behavioral characteristics and dimensions of the entrepreneurial mindset of professors and students, we performed the MannWhitney test with the collected data. The MannWhitney test is used to compare the positions between the two groups, making sure that the two populations have the same distribution, indicating equality in behaviors (Lopes 2016). Table 13 shows the results of the Mann-Whitney test for the collected data. When $\mathrm{p}>0.05$, it can be inferred that the two groups show equality in behavior.

Table 13. Correlation between entrepreneurial behavioral characteristics and dimensions of the entrepreneurial mindset of professors and students

\begin{tabular}{|c|c|c|}
\hline & Dimension/Characteristic & $\mathbf{P}$ \\
\hline \multirow{10}{*}{$\sum_{\substack{n\\
}}^{\infty}$} & $\begin{array}{l}\text { Search for opportunities and } \\
\text { initiative }\end{array}$ & 0.0600 \\
\hline & Persistence & 0.5852 \\
\hline & Commitment & 0.3692 \\
\hline & Demand for quality and efficiency & 0.1233 \\
\hline & Taking calculated risks & 0.5512 \\
\hline & Setting of goals & 0.8839 \\
\hline & Search for information & 0.1398 \\
\hline & Systematic planning and monitoring & 0.0320 \\
\hline & Persuasion and networking & 0.8174 \\
\hline & Independence and self-confidence & 0.9590 \\
\hline \multirow{5}{*}{ 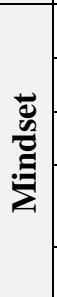 } & Autonomy & 0.1651 \\
\hline & Responsibility & 0.0007 \\
\hline & Will & 0.0479 \\
\hline & $\begin{array}{l}\text { Spirit of } \\
\text { initiative and problem solving }\end{array}$ & 0.2218 \\
\hline & Ability to manage func. relationships & 0.2917 \\
\hline
\end{tabular}

Source: created by the authors.

From the results of the Mann-Whitney test, it can be inferred that the group of professors and the group of analyzed students show behavior equality in relation to most of the behavioral characteristics and dimensions of entrepreneurial mindset, highlighted in gray in the table. The highest test values for the behavioral characteristics are for independence and selfconfidence (0.95), setting of goals (0.88) and persuasion and networking $(0.81)$, and the lowest for systematic planning and monitoring (0.03), the only behavioral characteristic where $\mathrm{p}<0.05$, indicating no equality in behavior between the groups.

Regarding entrepreneurial mindset, the dimension with the greatest correlation is the ability to manage functional relationships (0.29). Will showed the value of $p$ very close to the limit (0.047) and responsibility, as already identified above, was the dimension with the lowest correlation between professors and students (0.0007).

Com base em todos esses resultados que buscaram correlacionar as características comportamentais empreendedoras e a mentalidade empreendedora entre os docentes e discentes, em sua maioria indicando uma correlação entre os dois grupos investigados, pode-se inferir que o processo de aprendizagem na educação empreendedora ocorre de maneira complementar entre os professores e alunos investigados nesta pesquisa.

Leiva, Alegre and Monge (2014) describe three ways in which entrepreneurial learning may be acquired: formal, experimental and indirect. The formal way is through direct consultation with sources of information, instruction and training processes. The experimental way is from experience and how it then turns into knowledge. And the indirect acquisition occurs through observation of the behavior and actions of others, as well as your own results, with the approval or disapproval of the context and the reference group. In the case of under graduation, students learn through observation and interaction with their professors, and through the results they achieve together in this process. The image of the professor as an example of how to see things (mindset) and of action (behavior) has an indirect effect, but decisive, in the development of the entrepreneurial behavioral characteristics and mindset of students.

\section{Conclusions}

This research aimed to analyze the dimensions of the mindset and entrepreneurial behavioral characteristics of undergraduate students and professors in a higher education institution that develops entrepreneurial activities and education projects.

To be effective, entrepreneurial education

Revista de Negócios, v. 24, n. 2, p. 61-90, April, 2019. 
has to be based on an integrated, cross-curricular and interdisciplinary education, seeking to connect teaching, research and extension to the university environment, the ecosystem of the labor market and the local business environment. In addition, entrepreneurship should not be treated as an autonomous subject, as it is the case in a large part of higher education institutions, but integrated and cross-curricular in various subjects and courses, since the contents of other research fields intertwine. This way, we have an effective proposal for the entrepreneurial university.

The higher education institution investigated in this research develops entrepreneurial actions and activity projects in this regard, and the results obtained from its professors and students corroborate this scope. It may be inferred, from the results of this research, that aspects of mindset and behavior of entrepreneurs can be developed with reciprocity in professors and students from a proposal for entrepreneurial education. Entrepreneurs develop a type of mindset and a set of skills and abilities they use to create value for themselves and the society. And this process is always internal and external: Internal towards individual characteristics which determine a way of thinking (mindset), and external as its application in the environment as way of acting (behavior).

It was found in this study that, the analyzed professors, who, in the view of the students, perform unique and innovative activities, possess the 10 entrepreneurial behavioral characteristics. Stratifying them with a scale created for this study, 7 of them are configured with medium intensity (search for opportunities and initiative, commitment, demand for quality and efficiency, setting of goals, search for information, systematic planning and monitoring, and independence and self-confidence) and 3 characteristics showed low intensity (persistence, taking calculated risks, and persuasion and networking). The characteristic with the highest mean value was commitment, and the one with the lowest average was taking calculated risks. Regarding students, 6 behavioral characteristics exhibited mean values with medium intensity (search for opportunities and initiative, commitment, setting of goals, demand for quality and efficiency, search for information, and independence and self-confidence) and 4 characteristics showed low averages (persistence, taking calculated risks, systematic planning and monitoring and persuasion and networking). The characteristic with the highest mean value was setting of goals and the lowest average obtained was taking calculated risks.

Regarding the entrepreneurial mindset of the investigated professors, the highest proportional average between the dimensions of mindset is responsibility, and the smallest one is spirit of initiative and problem solving. From the means of the five dimensions, four of them show high intensity (autonomy, responsibility, will and ability to manage functional relationships) and one of them, spirit of initiative and problem solving, has medium intensity. In relation to students, the highest proportional average among the dimensions of mindset are responsibility and will, and the lowest proportional average is spirit of initiative and problem solving. All five dimensions of the entrepreneurial mindset of students presented mean values with medium intensity.

Comparing the results obtained from the studied professors and students, it is possible to identify a relationship between their mean values and intensities of entrepreneurial behavioral characteristics. Professors show means a little higher than the students, except for the characteristic setting of goals, in which the average of students is slightly higher. In the other characteristics the average of professors is higher, with the greatest difference for the characteristic systematic planning and monitoring. As in the results for the entrepreneurial behavioral characteristics, there is also a certain relationship in the results of the entrepreneurial mindset of the investigated professors and students. The dimension with the greatest difference is responsibility, with high intensity in professors and medium intensity in students, and the dimension with the closest values is spirit of initiative and problem solving, with medium intensity for both groups.

When verifying the relationships between entrepreneurial mindset and behavior in professors and students, it was initially examined the relationship between the entrepreneurial behavioral characteristics and dimensions of the mindset of the two groups separately, using Pearson's correlation coefficient. It was found that, in the professors, the correlations between the dimensions of entrepreneurial behavioral characteristics and dimensions of the 
entrepreneurial mindset were, mostly, positive associations, of very weak, weak and moderate intensities, indicating a direct relationship among them. Regarding the students, it was found that the correlations between the entrepreneurial behavioral characteristics and dimensions of entrepreneurial mindset were positive associations of very weak and weak intensities, mostly, what also indicates that there is a direct relationship among them.

Subsequently, it was verified the relationship between the results of entrepreneurial behavioral characteristics and dimensions of the entrepreneurial mindset of professors and students using the Mann-Whitney test. From the results, it may be inferred that the analyzed group of professors and the group of students have equality of behavior in relation to most of the behavioral characteristics and dimensions of the entrepreneurial mindset.

Based on these results, we can infer that the process of learning in entrepreneurial education occurs in a complementary manner among the investigated professors and students. By means of learning by formal, experiential and indirect acquisition, students develop behavioral and mindset characteristics along with their professors. This recognition and mutual alignment is important because it enhances the results of entrepreneurial education, seen that the way of thinking and acting of professors and students converge. The accomplishment of activities and integrated entrepreneurial training projects lead to the development of the mindset and the behavior of entrepreneurs in both students and professors.

\section{Implications and future research}

Based on the studies that were gathered and compared in this research, it may be stated, by investigating the behavior and mindset of entrepreneurs, that entrepreneurship is an essentially human process. A better understanding of this enterprising nature has been investigated scientifically and the development of the entrepreneurial spirit has been placed as a priority on the political, economic and academic agendas and debates from developing countries, in view of the positive influence that the entrepreneurial activity plays in social and economic development of a nation. In this direction and with this objective, for a greater understanding of the actions and behavior of entrepreneurs, one of the key elements that still needs to be better understood are the processes that are in the basis of their thinking, the processes from which entrepreneurial action is first conceived and then accomplished. This research aimed to join efforts in this direction in order to contribute to a greater understanding of the mindset and behavior of entrepreneurs. The understanding the entrepreneurial nature and how entrepreneurs think and act, from further research to investigate these issues, can guide the actions to be carried out with the purpose of creating, especially in emerging countries, entrepreneurial individuals, organizations and environments, which may create human development, competitiveness and economic growth, and social advancement.

This study was limited to the collection instruments developed by McClelland to evaluate the entrepreneurial behavioral characteristics and by Mencarelli to check the dimensions of entrepreneurial mindset in a cross section. Future studies may include new instruments to measure the way of thinking and acting of enterprising individuals, or even use the same collection instruments adopted in this research, but in a longitudinal study, in order to verify if there are changes and evolution in the development of the entrepreneurial mindset and behavior.

The data of this research were also limited to the Brazilian culture, through the analysis of professors and students of a private institution of higher education. One has to be cautious, therefore, in relation to the generalization of the results. It is suggested to enlarge the scope and allow inspections and confrontations, that the methodological procedures used in this study be replicated in new research in other educational institutions, both public and private. Comparative studies on entrepreneurial education initiatives and development of entrepreneurial mindset and behavior may bring benefits to management, teaching, research and extension of institutions both public and private. Besides that, future studies on the theme approached in this research may be carried out in other countries, in order to contribute to a greater understanding on the specificities of the entrepreneurial education in Brazil, as well as to allow an exchange of understandings and good practices among institutions of different nationalities. 


\section{References}

Amaral, M., Hernandez, C. T. \& Bastos, M. R. H. (2018). The entrepreneurial profile of Brazilian business administration students. International Journal of Innovation Science, 10(2), 160-177.

Araujo, G., \& Davel, E. (2019). Educação Empreendedora pela Experiência: $\mathrm{O}$ Caso do Festival de Artes Empreendedoras em Itabaiana. REGEPE - Revista de Empreendedorismo e Gestão de Pequenas Empresas, 8(1), 176-200.

Barini Filho, U. (2008). Transmissão da competência empreendedora: um estudo de casos múltiplos. (Tese de Doutorado). Universidade de São Paulo, São Paulo2008.São Paulo, SP, Brasil.

Coan, M. (2011). Educação para o empreendedorismo: implicações epistemológicas, políticas e práticas. (Tese de Doutorado). Universidade Federal de Santa Catarina, Florianópolis, SC, Brasil.

Collis, J. \& Hussey, R. Pesquisa em administração: um guia prático para alunos de graduação e pós-graduação. Bookman, 2005.

De Toni, D., Mioranza, G., Milan, G. S. \& Larentis, F. (2014). As dimensões dos modelos mentais dos empreendedores e seus impactos sobre o desempenho organizacional. READ Revista Eletrônica de Administração, 79(3), 713739.

Dheer, R. J. S. \& Lenartowicz, T. (2016). Multiculturalism and Entrepreneurial Intentions: Understanding the Mediating Role of Cognitions. Entrepreneurship Theory and Practice, DOI: 10.1111/etap.12260, 1-41.

Dolabela, F. \& Filion, L. J. (2013). Fazendo revolução no Brasil: a introdução da pedagogia empreendedora nos estágios iniciais da educação. Revista de Empreendedorismo e Gestão de Pequenas Empresas, 3(2), 134-181.

Dolabela, F. (2008). Oficina do empreendedor. Rio de Janeiro: Sextante.

Duarte, L. S., Debona, M. \& Perini, R. L. (2018) Perfil empreendedor do acadêmico do centro de negócios do Centro Universitário da Serra Gaúcha (FSG). Revista Global Manager Acadêmica, 7(1), 576-599.

Filion, L. J. \& Lima, E. (2010). As representações empreendedoras: importantes temas para avançar em seus estudos. Revista de Negócios, 15(2), 3252.

Guaranys, L. R.. (2010). Universidade empreendedora: conceito em evolução, universidade em transformação. In: Lopes, R. M. A. (Org.). Educação empreendedora: conceitos, modelos e práticas. Rio de Janeiro: Elsevier: São Paulo: SEBRAE.

Guerra, M. J. \& Grazzotin, Z. J. (2010). Educação empreendedora nas universidades brasileiras. In: Lopes, R. M. A. (Org.). Educação empreendedora: conceitos, modelos e práticas. Rio de Janeiro: Elsevier: São Paulo: SEBRAE.

Hair Jr., J. F.; Babin, B., Money, A. H. \& Samouel, P. (2005). Fundamentos de métodos de pesquisa em Administração. São Paulo: Artmed.

Henrique, D. C. \& Cunha, S. K. (2008). Práticas didático-pedagógicas no ensino de empreendedorismo em cursos de graduação e pósgraduação nacionais e internacionais. RAM Revista de Administração Mackenzie, 9(5), 112136.

Hirsch, R. D., Peters, M. P.\& Shepherd, D. A. (2014). Empreendedorismo. (9.) Porto Alegre: AMGH.

Krüger, C. (2019). Modelo de mensuração do comportamento empreendedor a partir das características comportamentais e intenção empreendedoras. (Tese de Doutorado). Universidade Federal de Santa Maria, Santa Maria, RS, Brasil.

Krüger, C. \& Minello, I. F. (2017). Educação empreendedora: características e atitudes. Sarbrücken: Novas Edições Acadêmicas.

Krüger, C., Pinheiro, J. P. \& Minello, I. F. As características comportamentais empreendedoras de David McClelland. Revista Caribeña de Ciencias Sociales, 2017. 
Lanero, A., Vázquez, J. L., Gutiérrez, P.. \& García, M. P. (2011). The impact of entrepreneurship education in European universities: an intention-based approach analyzed in the Spanish area. International Review on Public and Non-Profit Marketing, 8(2), 111-130.

Leiva, J. C., Monge, R. \& Alegre, J. (2014). The Influence of Entrepreneurial Learning in New Firms' Performance: A Study in Costa Rica. Innovar, 24 (N. Especial), 129-140.

Lima, E., Lopes, R. M. A., Nassif, V. M. J. \& Silva, D. (2015b). Ser seu Próprio Patrão? Aperfeiçando-se a educação superior em empreendedorismo. RAC, 19(4), 419-439.

Lima, E., Nassif, V. M. J., Lopes, R. M. A. \& Silva, D. (2014b). Educação Superior em Empreendedorismo e Intenções Empreendedoras dos Estudantes - Relatório do Estudo GUESSS Brasil. Caderno de pesquisa, n. 2014-03. São Paulo: Grupo APOE.

Lima, L. G. \& Nassif, V. M. J. (2017). Similitudes entre teoria social cognitiva, capital psicológico e comportamento empreendedor: uma reflexão teórica. Revista Gestão e Planejamento, 18 (1), 369-385.

Lopes, L. F. D. (2016). Métodos quantitativos. Santa Maria: Universidade Federal de Santa Maria.

Mansfield, R., S., McClelland, D. C., Spencer, L. M. \& Santiago, J. (1987) The identification and Assessment of competencies and other personal characteristics of entrepreneurs in Developing Countries. Boston: McBer\&Company.

Matias, M. A. \& Martins, G. A. (2012). Educação empreendedora em contabilidade. RBC: Revista Brasileira de Contabilidade, 41, 41-53.

McClelland, D. C. (1972). A sociedade competitiva: realização e progresso social. Rio de Janeiro: Expressão e Cultura.

McClelland, D. C. (1987). Characteristics of Successful Entrepreneurs. The Journal or Creative Behavior, 21(3). 219-233.
McClelland, D. C. (1978). Managing motivation to expand human freedom. American Psychologist, 33(1). 201-210.

Mencarelli, C. Test "Forma mentis". (2014). In: Dmitrieva, V. (Org.). The man in dialogue with the surrounding world: an ontopsychological approach. São Petersburgo: Imprensa Universitária.

Mendes, M. T. T. (2011). Educação Empreendedora: uma visão holística do empreendedorismo na educação. (Dissertação de Mestrado em Ciências da Educação). Universidade Católica Portuguesa, Lisboa, Portugal.

Minello, I. F. (2014). Resiliência e insucesso empresarial: o comportamento do empreendedor. Curitiba: Appris.

Minello, I. F., Bürger, R. E. \& Krüger, C. (2017). Características comportamentais empreendedoras: um estudo com acadêmicos de administração de uma universidade brasileira. Rev. Adm. UFSM, 10(Edição Especial), 72-91.

MSI - Management Systems International. Final Report: entrepreneurship training and the strengthening of entrepreneuria performance. 1990.

Nabi, G., Walmsley, A., Linan, F., Akhtar, I. \& Neame, C. (2018). Does entrepreneurship education in the first year of higher education develop entrepreneurial intentions? The role of learning and inspiration. Studies in Higher Education, 43(3), 452-467.

Oliveira, D. P. R. (2002). Sistema, organizações e métodos: uma abordagem gerencial. (13.) São Paulo: Atlas.

Ramos, M. P. (2013). Métodos Quantitativos e Pesquisa em Ciências Sociais: Lógica e Utilidade do Uso da Quantificação nas Explicações dos Fenômenos Sociais. Mediações - Revista de Ciências Sociais, 18(1), 55-65.

Ribas, R. (2011). O saber empreendedor: diretrizes curriculares para elaboração de

Revista de Negócios, v. 24, n. 2, p. 61-90, April, 2019. 
programas para formação de empreendedores com base na Escola Progressiva de John Deweyreflexão e proposta. (Tese de Doutorado), Pontifícia Universidade Católica de São Paulo, São Paulo, SP, Brasil.

Roesch, S. M. A. (2005). Projetos de Estágio e de Pesquisa em Administração. (3.), São Paulo: Atlas.

Sampieri, R. H., Collado, C. F. \& Lucio, M. P. B. (2013). Metodologia de Pesquisa. (5.) Porto Alegre: Penso.

Schaefer, R. (2018). Empreender como uma forma de ser, saber e fazer: o desenvolvimento da mentalidade e do comportamento empreendedores por meio da educação empreendedora. (Tese de Doutorado). Universidade Federal de Santa Maria, Santa Maria, Brasil.

Schaefer, R. \& Minello I. F. (2016). Educação Empreendedora: Premissas, Objetivos e Metodologias. Revista Pensamento Contemporâneo em Administração, 10(3), 60-81.

Schaefer, R. \& Minello I. F. (2017a). A Formação de Novos Empreendedores: Natureza da Aprendizagem e Educação Empreendedoras. Revista da Micro e Pequena Empresa FACCAMP, 11, 2-20.

Schaefer, R. \& Minello I. F. (2017b) Mentalidade empreendedora: o modo de pensar do indivíduo empreendedor. Revista de Empreendedorismo e Gestão de Pequenas Empresas, 6(3), 495-524.

Siluk, J. C. M., Garlet, T. B., Marcuzzo, R., Michelin, C. F. \& Minello, I. F. (2018). Empreendedorismo de Base Tecnológica no Sul do Brasil. REA UFSM, 11(2), 471-488.

Silva, J. F. \& Pena, R. P. M. (2017). O "be-á-bá" do ensino do empreendedorismo: uma revisão da literatura sobre os métodos e práticas da educação empreendedora. Revista de Empreendedorismo e Gestão de Pequenas Empresas, 6(2), 372-401.

Triviños, A. N. S. (2008). Introdução à pesquisa em ciências sociais: a pesquisa qualitativa em educação. São Paulo: Atlas.
Tschá, E. R. \& Cruz Neto, G. G. (2014). Empreendendo colaborativamente ideias, sonhos, vidas, e carreiras: o caso das células empreendedoras. In: GIMENEZ, F. A. P. et. al. (org.) Educação para o empreendedorismo. Curitiba: Agência de Inovação da UFPR.

Wood, M. S., Williams, D. W. \& Drover, W. (2017). Past as prologue: Entrepreneurial inaction decisions and subsequent action judgments. Journal of Business Venturing, 32, 107-127.

Yin, R. K. (2016). Pesquisa qualitativa do início ao fim. Editora Penso: Porto Alegre. 